\title{
Tax evasion, welfare fraud, and "the Broken Windows" effect: an experiment in Belgium, France and the Netherlands
}

\author{
Citation for published version (APA): \\ Lefebvre, M., Pestieau, P., Riedl, A. M., \& Villeval, M. C. (2011). Tax evasion, welfare fraud, and "the \\ Broken Windows" effect: an experiment in Belgium, France and the Netherlands. METEOR, Maastricht \\ University School of Business and Economics. METEOR Research Memorandum No. 023 \\ https://doi.org/10.26481/umamet.2011023
}

Document status and date:

Published: 01/01/2011

DOI:

10.26481/umamet.2011023

Document Version:

Publisher's PDF, also known as Version of record

\section{Please check the document version of this publication:}

- A submitted manuscript is the version of the article upon submission and before peer-review. There can be important differences between the submitted version and the official published version of record. People interested in the research are advised to contact the author for the final version of the publication, or visit the DOI to the publisher's website.

- The final author version and the galley proof are versions of the publication after peer review.

- The final published version features the final layout of the paper including the volume, issue and page numbers.

Link to publication

\footnotetext{
General rights rights.

- You may freely distribute the URL identifying the publication in the public portal. please follow below link for the End User Agreement:

www.umlib.nl/taverne-license

Take down policy

If you believe that this document breaches copyright please contact us at:

repository@maastrichtuniversity.nl

providing details and we will investigate your claim.
}

Copyright and moral rights for the publications made accessible in the public portal are retained by the authors and/or other copyright owners and it is a condition of accessing publications that users recognise and abide by the legal requirements associated with these

- Users may download and print one copy of any publication from the public portal for the purpose of private study or research.

- You may not further distribute the material or use it for any profit-making activity or commercial gain

If the publication is distributed under the terms of Article $25 \mathrm{fa}$ of the Dutch Copyright Act, indicated by the "Taverne" license above, 
Mathieu, Lefebvre, Pierre Pestieau, Arno Riedl, Marie Claire Villeval

Tax Evasion, Welfare Fraud, and "The Broken Windows"Effect: An Experiment in Belgium, France and the Netherlands

RM/ 11/023

\section{METEOR}

Maastricht University School of Business and Economics 


\title{
Tax Evasion, Welfare Fraud, and "The Broken Windows" Effect:
}

\author{
An Experiment in Belgium, France and the Netherlands
}

\author{
Mathieu Lefebvre ${ }^{\mathrm{a}}$, Pierre Pestieau ${ }^{\mathrm{b}}$, Arno Riedl $^{\mathrm{c}}$, Marie Claire Villeval ${ }^{\mathrm{d}}$
}

\begin{abstract}
February 2011
Abstract: In a series of experiments conducted in Belgium (Wallonia and Flanders), France and the Netherlands, we compare behavior regarding tax evasion and welfare dodging, with and without information about others' behavior. Subjects have to decide between a 'registered' income, the realization of which will be known to the tax authority for sure, and an 'unregistered' income that will only be known with some probability. This unregistered income comes from self-employment in the Tax treatment and from black labor supplementing some unemployment compensation in the Welfare treatment. Subjects have then to decide on whether reporting their income or not, knowing the risk of detection. The results show that $(i)$ individuals evade more in the Welfare treatment than in the Tax treatment; (ii) many subjects choose an option that allows for tax evasion or welfare fraud but report their income honestly anyway; (iii) examples of low compliance tend to increase tax evasion while examples of high compliance exert no influence; (iv) tax evasion is more frequent in France and the Netherlands; Walloons evade taxes less than the Flemish. There is no cross-country difference in welfare dodging.
\end{abstract}

JEL-Codes: H26, H31, I38, C91

Keywords: Tax evasion, social fraud, social comparisons, cross-country comparisons, experiments.

${ }^{a}$ University of Liège, CREPP, 7, Bd Rectorat (B31) Liège 4000, Belgium. mathieu.lefebvre@ulg.ac.be. Tel. : +32 43663042 ; Fax : +32 436693 18. Corresponding author.

b University of Liège, CREPP, 7, Bd Rectorat (B31) Liège 4000, Belgium; CORE, University of Louvain, CEPR and PSE; E-mail: P.Pestieau@ulg.ac.be. Tel. : +32 43663109 ; Fax : +32 43669318.

c School of Economics and Business, Maastricht University, P.O. Box 616, NL-6200 MD Maastricht, The Netherlands; CESifo, Munich, Germany; IZA, Bonn, Germany;. E-mail: a.riedl@maastrichtuniversity.nl. Tel. : +314338 84982; Fax : +31433884878.

d University of Lyon, Lyon, F-69007; CNRS, GATE, 93, Chemin des Mouilles, F-69130, Ecully, France; IZA, Bonn, Germany. E-mail: villeval@gate.cnrs.fr. Tel.: +33 4728660 79; Fax: +33 472866090. 


\section{INTRODUCTION}

Tax evasion and welfare frauds in both social assistance and insurance are worrisome phenomenas, in particular, but not only, in times of economic crises when tax bases decline while needs increase. Albeit its social and economic importance we know very little about these informal phenomena (see Andreoni, Erard, and Feinstein, 1998; Slemrod, 2007). The existing cross national and intertemporal estimates at the macro level pertaining to the size of underground activities are plagued with reliability problems. For instance, the indirect method used by Schneider (2004) and the survey method used in a recent Eurobarometer (European Commission, 2007) provide strongly diverging figures and rankings of countries concerning the extent of tax evasion. According to the former study the Belgian shadow economy is much larger than the French and the Dutch ones. In contrast, according to the latter study the Dutch seem to be much more involved in fraudulent activities than the other countries or regions. There is even less reliable evidence on underground activities at the micro level. However, for targeted policy action such as fighting tax evasion and curbing welfare dodging good micro data analysis is indispensable, because it provides information on the types of individuals that are involved and their behavioral motivations.

An important issue in policy debates concerns the relative importance of tax evasion and welfare dodging. Indeed, in times of scarcer public resources, it is even more important to focus spending on the deterrence of the most sizeable sources of fraud. A natural intuition is that these two types of fraud are related to populations with different income levels. From this perspective, the case of federal Belgium with its two main regions, Flanders and Wallonia, is an interesting case. Indeed, the conventional belief is that in rich Flanders tax evasion would be more widespread and welfare dodging less pervasive than in poorer Wallonia. It may however be the case that the two types of fraud are not only a matter of 
income level but are also associated with different social norms and levels of disapproval. In particular, it is conceivable that individual tax or welfare morale depends on the behavior of others in the society (Myles and Naylor, 1996; Alm and Torgler, 2006; Fortin, Lacroix, and Villeval, 2007; Torgler, 2007; Cummings et al., 2009). Recently, field experiments have indeed confirmed the "broken windows theory" of Wilson and Kelling (1982) which predicts that signs of disorder or littering induce the spreading of more disorder and littering when people can observe that others have violated a social norm (see notably Keizer et al., 2008). Therefore, one may suspect that a high level of compliance in the group may discipline individuals, while a low level of compliance may discourage them from behaving honestly. However, we do not know whether others' influence is the same on tax evasion and on welfare dodging. In addition, it is not clear that the disciplining effect -if any- of good examples is equivalent in size to the deteriorating impact of bad examples. Therefore this paper aims at measuring the relative importance of tax evasion and welfare fraud and whether and how both are influenced by social information about others behavior in both domains. These issues are difficult to address with conventional field empirical analyses because the available administrative data and households surveys are not accurate and informative enough. Another concern with field data is the difficulty to identify the impact of endogenous social interactions because of the reflection effect (Manski, 1993; Brock and Durlauf, 2001). Laboratory experiments constitute a useful approach here. They allow the controlled manipulation of the relevant factors of the environment, as income levels, monitoring probabilities, and information about others' behavior. Another advantage is that experiments allow to study individual behavior directly and to observe the causal effects to the introduction of exogenous changes, ceteris paribus. These advantages led to a series of experimental studies into tax evasion (see Alm, 1991; Webley et al., 1991; Andreoni, Erard, 
and Feinstein, 1998; Anderhub et al. 2001; Gerxhani and Schram, 2006; Fortin et al., 2007; Kirchler, 2007; Torgler, 2007; Coricelli et al., 2010), but none studied the equally important problem of welfare fraud, which is one main research question of our paper. The basic design of most experiments on tax compliance is as follows: subjects have to report their income knowing tax rates, audit probabilities and fines for underreporting income. Though there are varieties to this basic design, the results regarding tax compliance are robust. They show that compliance: (i) decreases with the tax rate; (ii) decreases with the level of income; (iii) increases with the audit probability; (iv) increases with the level of fines; (v) is higher when the proceeds are used to provide a public good; (vi) is usually lower than predicted if people are willing to maximize their earnings since a large subset of people never cheat, probably due to lie aversion. Indeed, it has been shown that tax evasion is not a gamble (Baldry, 1986) since it involves moral considerations and not only the maximization of individual earnings. To analyze whether individuals have the same attitude towards tax evasion and welfare dodging, we have designed an experiment that introduces the same monetary incentives to cheating in both. As in Gerxhani and Schram (2006) subjects choose between a 'registered' random income, the realization of which will be known to the tax authority for sure and taxed accordingly, and an 'unregistered' random income that will only be known with some probability. This unregistered income comes from self-employment in our Tax treatment and from black labor supplementing some unemployment compensation in our Welfare treatment. If subjects choose the unregistered income, after being informed on their actual income, they have to decide on whether reporting this income or not. If they do not report, they risk -if detected- a fine for underreporting or for working while drawing welfare benefits. These two treatments allow us to compare the extent of tax evasion and welfare fraud and their respective elasticity to income level, audit probability and level of fines. 
To measure the influence of others' behavior on tax evasion and welfare dodging and to compare the impact of "good" and "bad" examples, we have designed two variants of the previous decision situations. In these treatments with information, before making their decisions subjects received some information about the behavior of other subjects in past sessions. More precisely, for each audit probability and each level of fine we provided the minimum or maximum proportion of subjects in previous experimental sessions choosing the unregistered income and the minimum or maximum proportion of subjects who decided to report their income. In half of the sessions, we disseminated the minimum proportions, and in the other half the maximum proportions. In this way subjects received social information about the behavior of others that might influence their own behavior regarding tax evasion and welfare fraud. Subjects were not informed that these values corresponded to extremes. Importantly, all this information was conveyed in a non-deceptive way (see below for details).

We conducted the experiment in three European countries: Belgium (Flanders and Wallonia), France and the Netherlands. Flanders and Wallonia in Belgium share the same social and fiscal institutions but not necessarily the same values and social norms. Languages are the same in Wallonia and France, and in Flanders and the Netherlands, shaping potential cultural differences. We are thus able to compare behavior across countries (and within country for Belgium) when holding both our experimental institutions and information on others' behavior constant and, thus, contribute to the recent literature on cross-country experimental studies of tax evasion (Alm et al., 1995; Cummings et al., 2009; Alm and Torgler, 2006; Gerxhani and Schram, 2006; Torgler and Schneider, 2007; Lewis et al., 2009). Differences in behavior are observed across countries that can be related to cultural differences.

One main finding is that individuals engage more into welfare dodging than into tax evasion, independent of the social information conditions. This is surprising as the monetary 
incentives to cheat were kept constant across treatments. A second important finding is that many subjects choose an option that allows for tax evasion or welfare fraud but at the end decide to report their income honestly. A third important and novel result is that tax compliance is influenced by bad examples but not by good examples, while welfare dodging is unaffected by social information. Finally, we observe that tax evasion is more frequent in France and the Netherlands, that Walloons evade taxes less than the Flemish do when no information is available, but more when they learn about high evasion rates. There is no cross-country difference in welfare dodging.

The remainder of this paper is organized as follows. Section 2 presents our theoretical model. Section 3 details the experimental design and the procedures and it derives our predictions. Section 4 reports the experimental results. Section 5 discusses these results and concludes.

\section{THEORY}

The basic theoretical structure comes from the Allingham-Sandmo (A-S) model (Allingham and Sandmo, 1972). The model captures in a stylized way the taxpayer at the moment of filling in his income tax return: How much of his income should he report and how much should he evade?

Let $W$ be the gross income of the taxpayer and $t$ be a proportional income tax rate. The amount evaded, i.e. the amount of underreporting, is $E$, so that the reported income is $W$-E. If tax evasion is not detected, the net income of the taxpayer is accordingly: ${ }^{1}$

[1] $Y=W-t(W-E)=(1-t) W+t E$

\footnotetext{
${ }^{1}$ It should be pointed out that one obviously unrealistic simplification in this model is the assumption that all income is equally unknown to the tax collector. This is clearly not the case; in most countries earnings are reported to the tax authorities by the employer, so that this part of his income cannot in fact be underreported by the employee -unless he acts in collusion with his employer. The analysis should, therefore, be interpreted as applying to that part of his income that the taxpayer can in fact evade without certainty of detection.
} 
If, however, it is discovered that the taxpayer has underreported his income, he will pay a penalty rate, $T$, on the evaded amount, so that his net income in this case is:

[2] $Z=(1-t) W-(T-t) E$

The taxpayer's subjective probability of detection is $p$. He chooses the amount evaded so as to maximize his expected utility, which is:

[3] $V=(1-p) U(Y)+p U(Z)$

It is assumed that $U$ is increasing and concave, so that the taxpayer is risk averse. The firstorder condition for an interior solution is:

[4] $(1-p) U^{\prime}(Y) t-p U^{\prime}(Z)(T-t)=0$

or

[5] $U^{\prime}(Z) / U^{\prime}(Y)=(1-p) t / p(T-t)$

To see the empirical implications of the model one has to implicitly differentiate the first order conditions with respect to the exogenous variables $W, t, T$ and $p$. It is easily verified that the signs of the derivatives $\partial E / \partial T$ and $\partial E / \partial p$ are both unambiguously negative; a higher penalty rate or a higher probability of detection always tends to discourage tax evasion. It seems reasonable to assume that a higher gross income will increase evasion if one believes that people become more willing to engage in risky activities as they get richer. This is also predicted by the model but one has to make the additional and common assumption that the measure of absolute risk aversion is decreasing. As regards the effect of the regular marginal tax rate, a notable feature of this model is that an increase of the tax rate has an ambiguous effect on tax evasion. There is an income effect which is negative; higher taxes make the taxpayer poorer and, therefore, less willing to take risks. But there is also a substitution effect 
that works in the direction of increased evasion.

Up to now we have assumed that the individual was holding a self-employed occupation, which allowed him to conceal part of his earned income. Let us now assume that he has the choice between being self-employed with utility $V^{*}(W, t, T, p)$, the utility derived from selfemployment when the reported income is chosen optimally, and being salaried with observable income s and utility $U(s(1-t))$, where compliance is fully enforced. The individual will choose the salaried job and thus not to evade if

$V^{*}(W, t, T, p)<U(s(1-t))+\varepsilon$,

where $\varepsilon$ denotes a parameter reflecting a taste for compliance. It has been shown that heterogeneity among individuals regarding productivity, risk aversion (Pestieau and Possen, 1980), and taste for compliance can explain why some people decide to choose one or the other occupation. While the discussed models consist of three-stages (occupational choice, followed by tax report if self-employed and audits and penalties if caught cheating), we implement a four-stage decision problem consisting of:

1. Occupational choice

2. Random draw of income

3. Possible tax evasion if self-employed

4. Audits and penalties if caught cheating.

This model has the advantage that it is flexible enough to study tax evasion and welfare dodging in an equivalent way. The only difference is that, in the latter, stage 1 , the occupational choice, is one between salaried income and an income that can be concealed and thus combined with a welfare benefit at the risk of a heavy penalty.

Above we have introduced a parameter of compliance denoted $\varepsilon$. The higher this parameter, 
the more likely the "registered" occupation is to be chosen. This parameter can be exogenous, reflecting ethical or cultural values. It can also be endogenous reflecting some social norm that rests on aggregate choices. In our experiment there are conditions in which individuals are given the proportions of those who have chosen the registered occupation and of those who have chosen the unregistered occupation. In fact they are given either the maximum or the minimum proportion but which one is not specified. In that state of ignorance we can assume that the proportion given will be perceived as an average value and that individuals will be tempted to get as close as possible to that value by conformity or for social learning.

Formally the model assumes that the probability, $\pi$, that an individual chooses the registered occupation depends on the utility differential $\Delta=U-V$ and the proportion of non-evaders he is informed about, $\hat{\pi}$. We thus write: $\pi=\varphi(\Delta)+\varepsilon(\pi, \hat{\pi})$

and for simplicity assume:

$\pi=\varphi(\Delta)+A-\alpha(\pi-\hat{\pi})^{2}$ This latter expression reflects the desire to get as close as the indicated proportion perceived as the social norm. Both $A$ and $\alpha$ are positive parameters.

We easily check that $\pi$ is increasing with $\hat{\pi}$, which means that the actual proportion of individuals choosing the registered occupation is expected to be higher if the minimum rather than the maximum proportion of evaders is conveyed to the individuals.

\section{EXPERIMENTAL DESIGN AND PROCEDURES}

\subsection{Experimental design}

Our experiment is based on a $2 \times 2$ design. It consists of two treatments with 30 periods each, the Tax and the Welfare treatments, played under two conditions, the Information and No- 
Information conditions. It uses a combined within- and between-subject design.

\section{The treatments}

The two treatments have been designed such that they deliver the same predictions under the assumption of material self-interest and individual rationality. In both treatments people have to choose their source of income and we manipulate the probability of an audit and the level of sanctions in case of detected fraud.

The Tax treatment under the No-Information condition has been inspired by Gerxhani and Schram (2006) and consists of three stages. In the first stage of each period, the subjects choose their source of income by taking either a registered' income (a salaried job), the realization of which will be known to the tax authority for sure, or an 'unregistered' income (a self-employed job) that will only be known with some probability. Thus, the choice of the source of income informs on the willingness to evade taxes. Each job lasts one period and is associated with various possible gross incomes. In a salaried job, the gross income can take the value $200,300,450,550,650$ or 750 points, while in a self-employed job it can take the value $150,200,350,550,750$ or 850 points. The term "points" refers to the experimental currency unit. The earned points were converted into cash at the end of the experiment.

In the second stage, after the subjects have made their choice between a salaried job and a self-employed job, the computer program selects a gross income at random. The salaried wage is automatically taxed at $25 \% .^{2}$ If the individual has chosen a self-employed job, he has to make a second choice between reporting or not reporting his income. ${ }^{3}$ A reported income is taxed at $25 \%$ and no penalty is levied.

\footnotetext{
${ }^{2}$ This aims at capturing the fact that in salaried jobs tax evasion is made impossible by the fact that employers report the wage paid to the employees to the tax authorities.

${ }^{3}$ Alternatively, we could have asked the players to choose the amount to be reported. For the sake of simplicity, we only offered a binary choice.
} 
In the third stage, an audit can occur with a probability $p$, with $p \in\left\{\frac{1}{6}, \frac{1}{4}, \frac{1}{2}\right\}$, depending on the auditing condition. If an unreported income is detected, the gross income is taxed at $25 \%$ and a fine has to be paid. The fine amounts to $25 \%$ of the gross self-employment income plus a fixed amount $F^{f}$, with $F^{\prime} \in\{50,75\}$ depending on the fine condition in the respective period. Before choosing between a salaried job and a self-employed job, the subjects are informed on the values of $p$ and $F^{f}$ in the current period. At the end of each period, they are informed on whether they have been audited and on their net payoff.

The Welfare treatment under the No-Information condition is a variant of the previous treatment. The subjects have to choose between taking a 'registered' income (a salaried job), the realization of which will be known to the tax authority for sure, or cumulating a welfare benefit and a job on the black market. The difference with the previous treatment is that the alternative to the salaried job is always illegal as it is not allowed to cumulate a welfare benefit with a job on the black market, while only tax evasion in self-employed jobs is illegal. ${ }^{4}$ Therefore, the choice of the source of income indicates the willingness to cheat on the welfare system. The gross income in the salaried job can take the same values as in the Tax treatment (i.e., 200, 300, 450, 550, 650 or 750 points). By cumulating a welfare benefit and a job on the black market, the total gross income can take the value 150, 200, 350, 550, 750 or 850 points (which is equivalent to the self-employed-job income in the Tax treatment). Depending on the period, this includes a welfare benefit of 100 or 150 points, which means that the possible amounts earned on the black market are systematically 50 points lower when the welfare benefit is high than when it is low. ${ }^{5}$ The lost benefits in case of detection

\footnotetext{
${ }^{4}$ In both treatments, we mentioned that any income had to be reported. We did not specify, however, that cumulating a welfare benefit with a job on the black market is illegal but it was made clear from the payoff determination rules. Indeed, detected beneficiaries of a welfare allowance who hold a black market job automatically lose their welfare benefit -see details below.

${ }^{5}$ We vary the amount of the welfare benefit (that is lost in case of detection of fraudulent behavior) to guarantee
} 
correspond to the fines in the Tax treatment and are chosen such that the two treatments are payoff equivalent when analyzed under the classical assumptions on preferences and rationality. After the individuals have made their choice, the computer program selects a gross income at random. The salaried wage is automatically taxed at $25 \%$. If the subject has chosen to cumulate the welfare benefit and the job on the black market, he has to make a second choice between reporting or not reporting his black market income. Any reported income is taxed at $25 \%$ and leads to the withdrawal of the welfare benefit. ${ }^{6}$ If the income on the black market has not been reported, the probability of an audit $p$ is the same as in the previous treatment $\left(P \in\left\{\frac{1}{6}, \frac{1}{4}, \frac{1}{2}\right\}\right)$. If there is an audit, the welfare benefit is lost, the black market income is taxed at $25 \%$, and a fine has to be paid that amounts to $25 \%$ of the black market income. Before making their occupation choice, the subjects are informed on the probability of an audit and on the amount of the welfare benefit in the current period. At the end of the period, they learn whether they have been audited and their final payoff. Table 1 shows the payoffs associated with each possible situation. From this table the similarity of payoffs in both treatments is easily seen. In fact, all payoffs are the same in the Tax and Welfare treatments, except those associated with reporting decisions. This is due to the fact that cumulating black market income and welfare benefits is illegal while self-employment is obviously legal. We show in sub-section 3.2 that despite this difference, the classical predictions are the same in both treatments.

\section{(Table 1 about here)}

\section{Two social information conditions}

\footnotetext{
comparability with the two levels of fines in the Tax treatment.

${ }^{6}$ If the random black market income is equal to 0 and is reported (which is very unlikely), the sanction also applies (the welfare benefit is lost).
} 
In the No-Information condition, the subjects do not receive any information on others' behavior. However, in real settings people may have information about what others do. This information has potential effects on behavior due to social feedback effects (see Wilson and Kellig, 1982; Keizer et al., 2008). For this reason, we have implemented two different social information conditions for both the Tax and Welfare treatments. In the Tax (Welfare) treatment with social information, before making their occupation decision, the subjects are informed on the proportions of other subjects who chose the salaried job and the selfemployed job (cumulating black income and welfare benefit), respectively, in previous sessions for the given audit probability and fixed amount of the fine (welfare benefit). In addition, after learning their gross income the subjects who chose the self-employed job (cumulating, resp.) are informed on the proportion of individuals in some previous sessions who made the same choice, received the same gross income, and chose to report it, and the proportion of those who, in the same conditions, chose not to report their income. With this Information condition, we aimed at studying to which extent players were influenced by others' behavior. The design is such that we avoid the identification and reflection problems that impair identification with survey data.

Two variants of this condition have been implemented in each treatment. In some sessions, we implemented the "Info-Min condition", in which we displayed the minimum proportion of subjects choosing the self-employed job (cumulating the welfare benefit and the black market activity) ever observed in any session played under the No-Information condition in the Tax (Welfare) treatment. Thereafter, for those who chose self-employment (cumulating welfare benefit with black market activity), we displayed the minimum proportion of people choosing to not engage into fraud, i.e. reporting their self-employed income (black market income). In the opposite, "Info-Max condition", we displayed the corresponding maximum 
proportions ever observed in any session played under the No-Information condition. The subjects were not informed on the fact that we displayed extreme values as they received exactly the same instructions in the two variants of this condition (see Appendices A and B). ${ }^{7}$ These two opposite social information conditions allows us to investigate, first, whether there is any effect of such information and, second, whether the effect on behavior of a high and a low compliance example is symmetric. ${ }^{8}$

\section{Pre- and post-experimental questionnaires}

While it has been found that the likelihood of tax evasion is associated with a lower degree of risk aversion (Andreoni et al., 1998; Kirchler, 2007; Torgler, 2007), it is unknown whether this also holds for welfare fraud and whether risk attitude mediates the influence of social information on individual fraud behavior. To investigate this, we elicited our participants' risk attitude at the very beginning of all the sessions, using the Holt and Laury (2002) procedure (see also Cohen et al., 1987). Subjects made ten successive choices between two paired lotteries, "option A" and "option B" (see Appendix A). The payoffs for option A are either $€ 2$ or $€ 1.60$ and those for the riskier option $B$ are either $€ 3.85$ or $€ 0.10$. In the first decision, the high payoff in both options has a probability of one tenth and this probability increases by steps of one tenth as the number of the decision increases. Risk neutrality should lead subjects to cross-over from option A to option B at the fifth decision, while risk loving individuals are expected to switch earlier and risk averse individuals later.

At the end of each session, we recorded individual demographic characteristics and elicited

\footnotetext{
${ }^{7}$ There is no deception since we mention in the instructions "You also receive information on the decisions of participants who in some previous experiments were in the same conditions as you are now._More precisely, before making your decision, you are informed on the proportion of participants who chose the salaried job and the proportion of those who chose the self-employed job in previous experiments for the same audit probability and the same fixed amount of the fine as you." We also mentioned: "In these previous experiments the rules were the same as in this experiment, except that the participants did not have such information."

${ }^{8}$ The two conditions are really comparable since we used similar instructions. Thus, only the proportions indicated can possibly influence behavior. This would not have been possible if we had indicated that these proportions correspond to minimum or maximum values.
} 
attitudes towards tax evasion and illegal work and political orientations. A few questions were taken from the Eurobarometer survey on undeclared work in the European Union (European Commission, 2007). ${ }^{9}$ We also included questions on tax morale taken from the Taxpayer Opinion Survey (United States Department of the Treasury, 1987). ${ }^{10}$ Our aim was to relate our subjects' self-expressed tax morale and political orientations with their actual behavior in our experiment. Finally, to test the cognitive abilities of our subjects we added three questions from the Cognitive Reflection Test by Frederick (2005).

\subsection{Predictions}

Consider first the Tax treatment. The expected gross earnings amount to 483.33 points (S.D. $=208.97 ; \min =200 ; \max =750)$ in the salaried job and to 475 points $($ S.D. $=289.40 ; \min =$ $150 ; \max =850)$ in the self-employed job. Indeed, if incomes are reported, the expected net earnings amount to 362.5 in the salaried job and to 356.25 in the self-employed job.

Therefore, it is clear that for a risk neutral individual, the choice of the self-employed job in our environment should be only motivated by envisaged tax evasion. When $F^{f}=50$, the expected net earnings from not reporting are 427.08 points for $p=1 / 6,403.13$ for $p=1 / 4$, and 331.25 for $p=1 / 2$. When $F^{f}=75$, the corresponding expected net earnings from not reporting are $422.92,396.88$ and 318.75 points. This indicates that a risk neutral player should choose the self-employed job when the probability of an audit is lower than $1 / 2$ and the salaried job otherwise. The fixed amount of the fine should not affect this choice. ${ }^{11}$ Using the utility function and parameters as calculated in Holt and Laury (2002), we can show that an average risk averse player will instead choose the salaried job for $p=1 / 2$ and $p=1 / 4$, but

\footnotetext{
${ }^{9}$ In particular, we asked the subjects to which extent they find a series of behaviors related to fraud acceptable or not using a ten-point Likert-type scale.

${ }^{10}$ Subjects had to rate on a scale from 1 to 6 their feelings regarding the degree of acceptability of statements regarding tax fraud.

${ }^{11}$ These predictions hold for any income level, so learning one's own actual income should not change the decision to report or not to report it. However, for the minimum gross income of 150 points, $F^{f}=75$ and $p=1 / 4$, the subjects should be indifferent between reporting it or not as the expected earnings are 112.50 in both cases.
} 
will choose either the salaried job or the self-employed job when $p=1 / 6$ depending on his degree of risk aversion. In contrast, a risk seeking individual will choose the self-employed job for $p=1 / 6$ and $p=1 / 4$, but will choose the salaried or the self-employed job when $p=1 / 2$ depending on his degree of risk seeking. The value of $F^{f}$ does not affect these decisions.

Consider now the Welfare treatment. This treatment has been designed such that the expected net earnings when the welfare benefit amounts to 100 (150, respectively) are the same as in the Tax treatment when the fixed amount of the fine is 50 ( 75 , respectively). Therefore, this treatment delivers the same rational choice predictions. The expected gross earnings also amount to 483.33 points $($ S.D. $=208.97 ; \min =200 ; \max =750)$ in the salaried job and to 475 points $($ S.D. $=289.40 ; \min =150 ; \max =850)$ when cumulating a welfare benefit and a job in the black market. If incomes are reported, the expected net earnings amount to 362.5 in the salaried job and to 281.25 (243.75, respectively) when the welfare benefit is 100 (150, respectively). When the welfare benefit equals 100 (as when $F^{f}=50$ in the other treatment), the expected net earnings from not reporting are 427.08 points for $p=1 / 6,403.13$ for $p=1 / 4$, and 331.25 for $p=1 / 2$. When it equals 150 (as when $F^{f}=75$ ), the corresponding expected net earnings from not reporting are 422.92, 396.88 and 318.75 points. Therefore, a risk neutral subject should cumulate the welfare benefit and a job on the black market when the probability of an audit is lower than $1 / 2$ and the salaried job otherwise. The predictions for risk-seeking individuals are also the same as in the Tax treatment. Although the two treatments deliver the same predictions, it should be noted, however, that the expected earnings derived from reporting a self-employed job are higher than those derived from reporting an activity on the black market (true for any income level). This is due to the fact that reporting such an activity in the underground economy leads to the immediate withdrawal of the welfare benefit. Note, however, that such reporting behavior can never be 
optimal.These predictions are in line with the theoretical model of Section 2 where a higher penalty rate or a higher probability of detection tends to discourage evasion. From this perspective people should make the same decisions in both treatments and conditions and there should be no difference across countries. However, individuals may have a taste for tax compliance reflecting ethical or cultural values ( $\varepsilon$ in our model). Tax evasion may be more or less morally questionable than welfare dodging and depending on the institutions, behavior may differ across countries (see Alm and Torgler, 2006; Schneider, 2004; Halla and Schneider, 2009). Moreover, being informed on the behavior of others in previous sessions may affect individual decisions. Our model predicts that there should be more fraud in the Info-Max condition and less in the Info-Min condition compared with the No-Information condition.

\subsection{Procedures}

Our experiment was conducted in three countries and four different locations: at the Behavioral \& Experimental Economics Laboratory (BEElab) at Maastricht University (The Netherlands), at the Catholic University of Leuven (Belgium, Flanders), at the Groupe d'Analyse et de Théorie Economique (GATE-CNRS) in Lyon (France), and at the University of Liège (Belgium, Wallonia). ${ }^{12}$ This was not made common information to the subjects. The experiment was computerized using the REGATE-NG software developed at GATE (Zeiliger, 2000). Students were recruited from undergraduate classes in economics and business only, by means of the ORSEE software (Greiner, 2004). Only Dutch students participated in the Maastricht sessions, Flemish students in the Leuven sessions, Walloon students in the Liège sessions and French students in Lyon. In total, 513 people $(48.73 \%$ of whom were females) took part in 35 sessions. There were 257 subjects in the 17 sessions of

\footnotetext{
${ }^{12}$ In Lyon and Maastricht, we could use experimental labs. In Leuven and Liège, we used large lecture halls and a mobile lab, with enough space between participants to ensure the anonymity of decisions.
} 
the Tax treatment (50.19\% of whom were females) and 256 in the 18 sessions of the Welfare treatment (47.27\% of whom were females). The detail of these sessions is given in Table 2 .

In order to facilitate comprehension and to make sure that people understood that not reporting one's income means cheating on taxes, the instructions were phrased in non-neutral terms (see Appendices A and B). ${ }^{13}$ These instructions and the text of the screenshots have been written first in English language. Then, native speakers translated them into Dutch and French. A reverse translation to English has then been done and adjustments were made in each language to maximize the comparability between the French and Dutch instructions. The instructions in Dutch were used in Leuven and Maastricht; those in French were used in Liège and Lyon. With the help of local assistants, the same bilingual experimenter conducted all of the sessions in the three countries to avoid experimenter effects across countries.

\section{(Table 2 about here)}

We used the same random sequence of audit probability, fixed amount of fine, welfare benefit, and gross income in the four locations. To determine the values to be displayed in the Info-Min and the Info-Max conditions, we ran first all sessions with the No-Information condition. Then, by comparing these sessions, we identified for each audit probability and each value of the fixed fine and welfare benefit the minimum and the maximum observed proportions of participants choosing the self-employed job or cumulating the welfare benefit and the black market job. Similarly, we determined the minimum and maximum proportions of individuals reporting and not reporting their income for each level of gross income.

Upon arrival, each subject was assigned a computer randomly. The instructions for the first part (i.e. risk preference elicitation) were distributed and read aloud by the experimenter. After having their questions answered in private, subjects made their ten lottery choices. No

\footnotetext{
${ }^{13}$ We used notions like income, tax, welfare benefit, black market job, audit, and fine. The instructions did not include any loaded terms such as fraud, cheating, or evasion.
} 
feedback was given on the outcomes of this part before the end of the session. After all the subjects completed this part, we distributed and read aloud the instructions for the next part (the Tax or Welfare treatment). A comprehension questionnaire was administered to check that the rules were well understood. All questions were answered in private. Once the 30 periods of this part were completed, the screens displayed the post-experimental questionnaire. Then, at the end of the session, subjects were paid their earnings in a separate room and in private. In the payment room, we first played the lottery of the first part. Each subject rolled a ten-sided die to determine which decision number would be played for real. For the selected decision, the subject rolled the die gain for determining the payoff in the lottery chosen in the lottery task.

In each treatment, there was a conversion rate of 100 experimental points to $€ 3$. Two of the 30 periods were randomly drawn for payment at the end of the session. Average earnings were $€ 16.86$ (standard deviation $=4.72$ ), including a $€ 3$ show-up fee. A session lasted on average 54 minutes excluding payment.

\section{RESULTS}

First, we give an overview of the choices of tax evasion and welfare dodging by country and information condition. This descriptive analysis is followed by a regression analysis of the determinants of fraudulent behavior in each treatment and condition.

\subsection{Descriptive analysis}

Table 3 displays the average percentage of individuals who chose one or another occupation as well as the percentage of evaders (related to the total number of subjects by treatment and/or condition) in both treatments. In the welfare treatment, we report both those who 
decide to cumulate a black market job and the welfare benefit and those who cumulate and do not report their income on the black market. Table 3 displays both measures.

\section{(Table 3 about here)}

Table 3 indicates that the percentage of evaders (stricto sensu-related to those who did not chose the registered income- or not) is higher in the Welfare than in the Tax treatment although they should be similar theoretically. This is true in almost all information conditions. Indeed, Mann-Whitney tests (M-W thereafter), considering conservatively each individual as one unit of observation and holding the stricto sensu definition of evasion, indicate that the difference between treatments is significant when all data are pooled $(p=$ $0.002)$, in the No-Information condition $(p=0.058)$, in the Info-Min condition $(p=0.064)$, but not in the Info-Max condition $(p=0.139) .{ }^{14}$ When data are pooled, the difference in the percentage of evaders between the Tax and Welfare treatments is significant in Flanders $(p=$ $0.046)$ and Wallonia $(p=0.008)$, but not in France $(p=0.277)$ or the Netherlands $(p=0.544)$.

Regarding the Tax treatment, Table 3 shows that the percentage of individuals who choose the self-employed job is higher in France and the Netherlands than in the Belgian regions, but pair-wise tests indicate that only Wallonia and the Netherlands differ significantly $(\mathrm{M}-\mathrm{W}, p=$ 0.027 when all data are pooled and $p=0.040$ for the sole No-Information condition $)^{15}$. Looking at the proportion of evaders, Wallonia has the lowest proportion closely followed by Flanders. The difference is significant between Wallonia and France $(\mathrm{M}-\mathrm{W}, p=0.066$ when all data are pooled, and $p=0.015$ for the No-Information condition) and between Wallonia and the Netherlands (M-W, $p=0.021$ and $p=0.005$, respectively). But there is no difference between the two Belgian regions.

\footnotetext{
${ }^{14}$ If we accept the broader definition of evasion, the $p$-values are respectively $<0.001,<0.001,0.023$, and 0.008 .

${ }^{15}$ The difference between Wallonia and the Netherlands is no more significant when we correct $p$-values for multiple testing.
} 
Interestingly, we also observe that while $60.64 \%$ of the subjects choose an occupation that allows for tax evasion, $32.96 \%$ of them report their income anyway, which is not in line with the theoretical predictions for risk-neutral individuals. This behavior could be attributed to mental accounting, assigning different statuses to the two sources of money (income and evaded taxes), to isolation if subjects valuate separately each of the two stages of the decision process, or to excess optimism if subjects choose self-employment not because it offers the perspective of tax evasion but in the hope of receiving the maximum possible income (i.e. 637.5 with the self-employed job and 562.5 with the registered job). In the Welfare treatment, the percentage of those cumulating a welfare benefit and an unreported job is similar across countries as well as the percentage of subjects who do not report their black market income (M-W, $p>0.30$ in all pair-wise comparisons).

According to Table 3, the introduction of social information concerning choices in previous experiments does not influence behavior symmetrically in the Tax and the Welfare treatments. In the Tax treatment, the percentage of participants who choose the selfemployed job is significantly higher in the Info-Max condition than in the No-Information condition (M-W, $p=0.065$ for all the countries pooled together, and $p=0.004$ for Wallonia) and than in the Info-Min condition (M-W, $p=0.052$ and $p=0.007$ for Wallonia). There is no difference between the No-Information and the Info-Min conditions $(\mathrm{M}-\mathrm{W}, p=0.807)$. There is no significant difference either in the percentage of evaders between conditions, except for Wallonia $(\mathrm{M}-\mathrm{W}, \mathrm{p}=0.008)$. Regarding the Welfare treatment, the dissemination of examples does not modify compliance (M-W, $p>0.10)$. This is also true at the country level.

Finally, Figure 1 displays the relative frequency of evaders (stricto sensu) by treatment, country and audit probability.

(Figure 1 about here) 
The theoretical predictions are that a risk-neutral subject should not evade when the audit probability is $50 \%$ and should not comply for lower audit probabilities. The observed behavior deviates significantly from this prediction, showing evidence of risk seeking behavior when the probability of an audit is high and risk-averse behavior when the probability is low or medium, which is consistent with Prospect theory. ${ }^{16}$

\subsection{The determinants of tax evasion and welfare dodging}

We analyze the determinants of fraudulent behavior first by pooling together the data from the Tax and the Welfare treatments and then by considering each type of fraud separately.

First, we estimate the probability of tax and welfare fraud by means of a Probit model with robust standard errors and clustering at the individual level to control for the fact that each subject makes 30 decisions. The dependent binary variable indicates whether the subject has or has not concealed his income. The first set of independent variables includes dummy variables for the Tax treatment, the Info-Min and the Info-Max conditions (with the NoInformation condition as the reference), each audit probability (with the probability $1 / 6$ as the reference), and the high fixed fine in case of detected fraud. The second set of independent variables includes dummies for each country or region (with Wallonia as the reference category).

The third set of independent variables consists of time-invariant individual characteristics. More specifically, this includes gender, age, cognitive performance (measured by the number of correct answers in the Cognitive Reflection Test), and the parents' relative income category (between 1 if the subject believes his parents' income is among the lowest $10 \%$ compared to that of the other students of his school and 10 if he believes it is among the highest $10 \%$ ). We

\footnotetext{
${ }^{16}$ The probability of evasion is significantly different from 0 when the audit probability is .5 both in the Tax treatment (t-tests with each individual as a unit of observation, $p<0.001)$ and in the Welfare treatment $(p<$ $0.001)$. This probability is systematically different from 100 for the other audit probabilities $(p<0.001)$.
} 
control for risk attitude both with the safety index given by the number of safe choices in the Holt and Laury lottery and with the self-reported risk attitude variable for which a low value indicates, in contrast, higher risk aversion. We also control for the individual's opinions on tax morale and undeclared work by considering the degree of acceptability of four statements in the post-experimental questionnaire:

- Almost every taxpayer would cheat to some extent if s/he thought s/he could get away with it (labelled "Cheat if get away" hereafter)

- Being paid in cash for a job and then not reporting it on your tax form (labelled "Pay in cash" hereafter)

- Someone evades taxes by not or only partially declaring income (labelled "Tax evasion" hereafter)

- Someone receives welfare payments without being legally entitled (labelled "Social fraud" hereafter) ${ }^{17}$

We also include one binary measure of political opinion related to progressive tax policies (labelled "Rich pay too much taxes"). ${ }^{18}$ Finally, we include a time trend to control for a possible learning effect over time.

The same model is estimated on pooled data and on each condition separately. Table 4 displays the results of these regressions.

(Table 4 about here)

Table 4 indicates that individuals evade significantly less in the Tax treatment than in the Welfare treatment although both give the same theoretical predictions. The marginal effect of this treatment is $-6 \%$ when data are pooled. Indeed, in the Tax treatment some individuals choose the self-employment job but decide not to evade taxes, possibly due to mental accounting, isolation, or the hope of getting the highest possible income and reporting it,. In

\footnotetext{
${ }^{17}$ The first two statements are taken out from the TOS survey and are rated on a scale from 1 (perfectly acceptable) to 6 (perfectly unacceptable). The last two statements are taken out from the Eurobarometer and are rated in the opposite direction from 1 (absolutely unacceptable) to 10 (absolutely acceptable).

${ }^{18}$ This variable is coded 1 if the subject has agreed or strongly agreed with the following statement: "The rich have to pay too much taxes", and 0 otherwise.
} 
the Welfare treatment reporting an illegal activity is always sanctioned; therefore it is probably more salient than in the Tax treatment that not taking the salaried job but reporting one's income in the second stage leads to lower payoffs.

Interestingly, we find a small (3.16\%) but significant positive effect of the Info-Max condition on evasion $(p=0.079)$. This indicates that controlling for individual characteristics and the deterrence policy, observing examples of relatively low compliance levels motivates some individuals to evade more, while observing examples of high compliance does not discourage fraud. At the aggregate level, the likelihood of evasion is similar across countries except for the French participants who evade more and get closer to the theoretical predictions than the participants from the other countries. When no information is available, the Wallonian participants evade significantly less than the participants in any other country; but in the Info-Max condition, Wallonians evade as much as the French participants, and significantly more than the Flemish and the Dutch participants. In contrast, when the InfoMin condition prevails, there are no cross-country differences.

The other results are standard. Compared with an audit probability of $1 / 6$, an audit probability of $1 / 4$ reduces the likelihood of evading by $23.50 \%$ and a probability of $1 / 2$ reduces it by $64.90 \%$ when all conditions are considered. The high fine also decreases evasion. The negative impact of audits and fines is consistent with previous experiments and with evidence based on survey data (Friedland et al., 1978; Dubin et al.,1990; Slemrod et al., 2001). As regards individual characteristics, in accordance with the previous experimental literature, males evade more than females (Spicer and Becker 1980, Baldry 1986). Elicited or selfreported risk attitudes consistently indicate that more risk averse players are less likely to evade. The self-reported risk attitude influences the evasion decision to the same extent in the three conditions. In contrast, the impact of the risk attitude as measured by the Holt and 
Laury (2002)'s procedure differs across information conditions although the risk associated with the fraud decision is the same. This effect is hardly significant when no information is available, while switching lotteries one decision later (= being more risk averse) decreases the likelihood of evasion by $3.6 \%$ in the Info-Max condition and by $4.7 \%$ in the Info-Min condition. Interestingly, the cognitive performance is associated with a higher probability to evade, which makes sense since the rational behavior in this experiment is to evade provided the audit probability is lower than $50 \%$. This effect is mainly driven by the Info-Max condition. The individuals who report a higher acceptability of tax evasion are more likely to evade, but this result may be interpreted as self-justification.

In the following, we analyze the determinants of fraudulent behavior in each treatment. The results are presented in Table 5. To supplement the previous analysis in which we do not control for possible sample selection, we estimate here a two-step Probit model with sample selection as the choice to evade income is conditional on the choice of the occupation. Thus, we first estimate the determinants of the occupational choice by means of a Probit model (Eq. 1 and 3). We then explain the decision to evade, conditional on that decision, with another Probit model (Eq. 2 and 4). In all the estimations we calculate robust standard errors and we cluster the observations at the individual level. Equations 1 and 2 refer to the Tax treatment and equations 3 and 4 to the Welfare treatment. Since the two treatments are symmetric, the specifications are the same. The independent variables are the same as in Table 4, except that we include in the conditional equations the gross income divided by 100 . This is reasonable because participants are informed on their actual income after they have made their occupational choice but before they decide to report on not their income.

(Table 5 about here)

Table 5 indicates that the Info-Max condition exerts a significant and positive impact only on 
the decision to choose self-employment in the Tax treatment. Its marginal effect is $6.35 \%$. Estimation (1) shows that France and the Netherlands have a higher probability to choose self-employment compared to Wallonia, with no difference within Belgium. Conditional on this decision, the French subjects are also more likely to evade than the other subjects (Estimation (2)). A higher cognitive performance leads to a more likely choice of selfemployment, which is consistent with the fact that better cognitive abilities should help finding the optimal choice. More risk-averse participants are less likely to choose selfemployment and, conditional on this choice, to evade. Males and females choose selfemployment with the same likelihood but males tend to evade more in the second stage (only significant at the $10.3 \%$ level). Regarding opinions, the subjects who find tax evasion a more acceptable behavior or think "the rich pay too much taxes" are also more likely to choose the self-employed job. Conditional on this choice, individuals who receive a higher experimental income are more likely to evade taxes, as well as those whose parents are relatively wealthier. Regarding the Welfare treatment, estimation (3) shows that the choice of cumulating a black market job and a welfare benefit reacts mainly to the audit probability, the level of the fine, and risk attitudes. We do not find any influence of the information condition, country, opinions or cognitive performance. The same is observed in estimation (4), except that males are more likely to evade in the second stage of the experiment, as well as those who think that "being paid in cash for a job and then not reporting it on the tax form" is more acceptable.

\section{CONCLUSION}

Research on the informal sector in general and tax evasion or welfare dodging in particular is an important enterprise. Unfortunately, it is notoriously difficult to obtain reliable evidence on these behaviors from the field. For that reason, we have designed a laboratory experiment in 
which subjects can choose between a registered and an unregistered source of income like in Gerxhani and Schram (2006). Importantly, we extended their analysis by including welfare dodging and exploring the potential effect of social information regarding others' behavior. Our objectives in this study were mainly $(i)$ to compare decisions regarding tax evasion and welfare dodging in a framework that delivers the same predictions under classical assumptions; (ii) to analyze whether each of these decisions are influenced by social information about others' behavior and if this influence, if any, is symmetric when information conveys examples of high compliance or examples of low compliance; (iii) to compare tax evasion and welfare dodging in various countries of the Euro zone for which conventional beliefs predict differences in behavior. Our findings are that welfare dodging is more frequent than tax evasion. In light of the identical theoretical predictions this is surprising. A reason for this result may be that a fraction of the participants who chose the self-employed job instead of the automatically reported salaried job in the first stage do not always evade taxes in the second stage. In contrast, most of those who choose to cumulate a black market job and the welfare benefit instead of choosing the automatically reported salaried job have clearly no reason to report their income, because this report is punished with certainty by the withdrawal of the welfare benefit. Therefore, the net incomes in case of reported non-salaried activity are lower in the Welfare treatment than in the Tax treatment. Therefore if the individuals do not base their decision on the expected profits of evasion but on the absolute difference between the net income in case they report and the net income in case they do not, this could explain the observed higher frequency of fraud in the Welfare treatment than in the Tax treatment. Alternatively, the fact that some subjects choose the selfemployed job but report their income anyway could be attributed to mental accounting or to isolation if subjects consider separately each of the two stages of the decision process. These 
behavioral explanations, however, cannot explain the difference between the two treatments. Finally, another possible explanation of the higher fraud in the Welfare treatment is that welfare dodging is considered as morally more acceptable than tax evasion. Further studies would be required to better understand the ultimate motivations driving this result.

We did not find cross-country differences in welfare dodging, while tax evasion is more frequent in France and the Netherlands than in the Belgian regions; in the latter country, Walloons evade taxes less than the Flemish do when no information is available, but more when they learn about high evasion rates.

Indeed, another main finding is that there is a significant effect of social information about others' behavior on the individual decision to engage in tax evasion, but not in welfare fraud. In the Tax treatment the effect is asymmetric as "bad" examples of low compliance significantly increase tax evasion while disseminating "good" examples of high levels of compliance does not influence evasion decisions at all. This asymmetric effect is a novel result. The negative effect of bad examples on tax compliance is consistent with the so-called "broken windows" theory according to which individuals feel less committed to honesty if they can observe that others do not comply. In our experiment the effect is strongest for the sub-population of subjects characterized by a lower level of evasion when no information about others was available (namely, the Walloon sub-sample of participants). This asymmetric effect suggests that in this environment social information tends to support less conformity than social learning by reducing the moral cost of tax evasion. A pure conformity effect should have increased average compliance when information on the highest compliance was disseminated. This interpretation should be further explored. Our results also suggest that, from a policy perspective, it is better not to reveal information on tax compliance behavior. One can wonder whether informing on detection would have a different impact. 
Acknowledgements: The authors are grateful to Sylvain Ferriol for programming the experiment. They wish to thank Frederic De Wispelaer, Jozef Pacolet and Sergio Perelman for their help in the implementation of the experiments. Financial support from Belgian Science Policy (SUBLEC AG/JJ/137) and from the Belgium's French Community (ARC $05 / 10-332)$ is gratefully acknowledged.

\section{References}

Allingham, M., A. Sandmo, 1972. "Income Tax Evasion: A Theoretical Analysis", Journal of Public Economics 1(3-4), 323-338.

Alm, J., 1991. "A Perspective on the Experimental Analysis of Taxpayer Reporting”, The Accounting Review 66, 577-593.

Alm, J., G.H. McClelland, and W.D. Schulze, 1992. "Why do people pay taxes?", Journal of Public Economics 48, 21-48.

Alm, J., Sanchez, I., de Juan, A., 1995. "Economic and non-economic factors in tax compliance", Kyklos, 48, 3-18.

Alm, J., and B. Torgler, 2006. "Culture differences and tax morale in the United States and in Europe", Journal of Economic Psychology 27, 224-246.

Anderhub, V., S. Giese, W. Guth, A. Hoffmann and T. Otto, 2001. "Tax Evasion with Earned Income - An Experimental Study", FinanzArchiv 58(2), 188-212

Andreoni, J., B. Erard, and J. Feinstein, 1998. "Tax Compliance", Journal of Economic Literature 36, 818-860.

Baldry, J.C., 1986. "Tax evasion is not a gamble”, Economics Letters 22, 333-335.

Bernasconi, M., and A. Zanardi, 2004. "Tax evasion, tax rates, and reference dependence", FinanzArchiv: Public Finance Analysis 60(3), 422-445.

Brock, W.A., Durlauf, S.N., 2001. Interactions-Based Models, in J. Heckman and E.

Leamer, eds., Handbook of Econometrics 5, Elsevier Science B.V., 3297-380.

Cohen, M., J-Y. Jaffray and T. Said, 1987. "Experimental Comparison of Individual Behavior under Risk and under Uncertainty for Gains and Losses", Organizational Behavior and Human Decision Processes, 39, 1-22.

Coricelli, G., M. Joffily, C. Montmarquette and M.C. Villeval, 2010. "Cheating, Emotions and Rationality: An Experiment on Tax Evasion", Experimental Economics 13, 226-247.

Cowell, F., 1990. Cheating the Government: The Economics of Evasion. Cambridge, MA: MIT Press. 
Cummings, R.G., J. Martinez-Vazquez, M. McKee, and B. Torgler, 2009. "Tax morale affects tax compliance: Evidence from surveys and artefactual field experiments", Journal of Economic Behavior and Organization 70(3), 447-457.

Dohmen, T., A. Falk, D. Huffman, U. Sunde, J. Schupp, and G. G. Wagner, 2010. "Individual Risk Attitudes: Measurement, Determinants and Behavioral Consequences", Forthcoming in Journal of the European Economic Association.

Dubin, J.A., Graetz, M.J., Wilde, L.L., 1990. “The Effect of Audit Rates on the Federal Individual Income Tax, 1977-1986”, National Tax Journal 43(4), 395-409.

European Commission, 2007. Eurobarometer Survey on Undeclared Work in the European Union, 284, Luxemburg.

Fortin, B., G. Lacroix, and M.C. Villeval, 2007. "Tax Evasion and Social Interactions", Journal of Public Economics 91, 11-12, 2089-2112.

Frederick, S., 2005. "Cognitive reflection and decision making", Journal of Economic Perspectives, 19(4), 25-42.

Friedland, N., Maital, S., Rutenberg, A., 1978. “A Simulation Study of Income Tax Evasion”, Journal of Public Economics 10, 107-116.

Gerxhani, K. and A. Schram, 2006. "Tax evasion and income source: A comparative experimental study", Journal of Economic Psychology 27(3), 402-422.

Greiner, B., 2004. An Online Recruitment System for Economic Experiments. In: K. Kremer, V. Macho, Eds, Forschung und wissenschaftliches Rechnen 2003. GWDG Bericht 63; Göttingen: Ges. für Wiss. Datenverarbeitung; 2004. p. 79-93.

Halla, M. and F.G. Schneider, 2009. Taxes and Benefits: Two Distinct Options to Cheat on the State? Research paper, IZA.

Holt, C. A., and S. K. Laury, 2002. "Risk Aversion and Incentive Effects", American Economic Review 92(5), 1644-1655.

Keizer, K., S. Lindenberg, and L. Steg, 2008. "The Spreading of Disorder”, Science 322, 1681-1685.

Kirchler, E., 2007. The Economic Psychology of Tax Behaviour. Cambridge: Cambrigde University Press.

Lewis, A., S. Carrera, J. Cullis, and P. Jones, 2009. "Individual, cognitive and cultural differences in tax compliance: UK and Italy compared", Journal of Economic Psychology $30(3), 431-445$.

Manski, C.F., 1993. Identification of Endogenous Social Effects: The Reflection Problem.

Review of Economic Studies 60(3), 531-42.

Myles, G.D. and R.A. Naylor, 1996. "A Model of Tax Evasion with Group Conformity and Social Customs", European Journal of Political Economy 12(1), 49-66.

Schneider, F., and D.H. Enste, 2002. The shadow economy - An international survey. Cambridge: Cambridge University Press.

Schneider, F., 2004. "Shadow Economies of 145 Countries all over the World: Estimation Results over the Period 1999 to 2003," IZA Discussion Paper n 1431, Bonn. 
Slemrod, J., 2007. "Cheating Ourselves: The Economics of Tax Evasion", Journal of Economic Perspectives 21(1), 25-48.

Slemrod, J.B., Blumenthal, M., Christian, C., 2001. "Taxpayer response to an increased probability of audit: evidence from a controlled experiment in Minnesota", Journal of Public Economics 79, 455-483.

Torgler, B., 2007. Tax Compliance and Tax Morale. A Theoretical and Empirical Analysis. Cheltenham: Edward Elgar.

Torgler, B. and F. Schneider, 2007. "What Shapes Attitudes Toward Paying Taxes? Evidence from Multicultural European Countries”, Social Science Quarterly 88 , 443-470.

United States Department of the Treasury, 1987. Taxpayer Opinion Survey. Internal Revenue Service, ICPSR 8927.

Webley, P., H. Robben, H. Elffers, and D. Hessing, Eds., 1991. Tax evasion: An experimental approach. Cambridge: Cambridge University Press.

Wilson, J.Q. and G.L. Kelling, 1982. "Broken Windows: The Police and Neighborhood Safety", Atlantic Monthly 249, 29-38.

Yitzhaki, S., 1974. "A note on 'Income Tax Evasion: A Theoretical Analysis', " Journal of Public Economics 3(2), 201-202.

Zeiliger, R., 2000. "A Presentation of Regate", Internet-Based Software for ExperimentalEconomics,http://www.gate.cnrs.fr/ zeiliger/regate/RegateIntro.ppt. Lyon: GATE. 


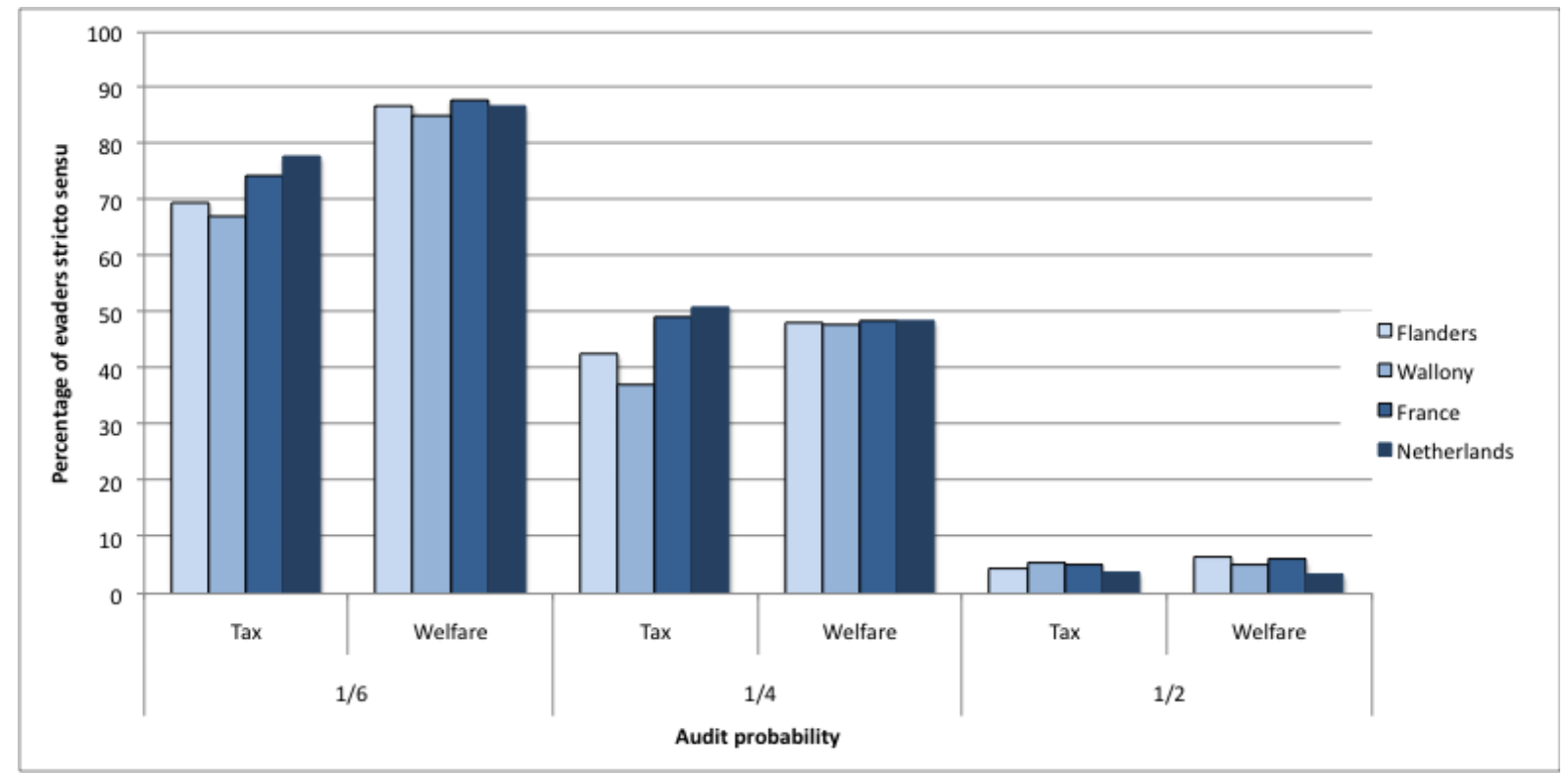

Fig.1. Relative frequency of fraud by treatment, country, and audit probability 
Table 1. Net payoffs in the Tax treatment and the Welfare treatment

\begin{tabular}{|c|c|c|c|c|c|c|}
\hline \multicolumn{7}{|c|}{ Tax treatment } \\
\hline Salaried job & 150 & 225 & 337.5 & 412.5 & 487.5 & 562.5 \\
\hline \multicolumn{7}{|l|}{ Self-employed job } \\
\hline Report & 112.5 & 150 & 262.5 & 412.5 & 562.5 & 637.5 \\
\hline No report, no audit & 150 & 200 & 350 & 550 & 750 & 850 \\
\hline No report, audit, $F^{f}=50$ & 25 & 50 & 125 & 225 & 325 & 375 \\
\hline No report, audit, $F^{f}=75$ & 0 & 25 & 100 & 200 & 300 & 350 \\
\hline \multicolumn{7}{|c|}{ Welfare treatment } \\
\hline Salaried job & 150 & 225 & 337.5 & 412.5 & 487.5 & 562.5 \\
\hline \multicolumn{7}{|c|}{ Cumulating welfare benefit $(=100)$ and black market job } \\
\hline Report & 37.5 & 75 & 187.5 & 337.5 & 487.5 & 562.5 \\
\hline No report, no audit & 150 & 200 & 350 & 550 & 750 & 850 \\
\hline No report, audit & 25 & 50 & 125 & 225 & 325 & 375 \\
\hline \multicolumn{7}{|c|}{ Cumulating welfare benefit $(=150)$ and black market job } \\
\hline Report & 0 & 37.5 & 150 & 300 & 450 & 525 \\
\hline No report, no audit & 150 & 200 & 350 & 550 & 750 & 850 \\
\hline No report, audit & 0 & 25 & 100 & 200 & 300 & 350 \\
\hline
\end{tabular}

Note: Numbers are in experimental points. 
Table 2. Details of the experimental sessions by location

\begin{tabular}{lccccc}
\hline \multicolumn{1}{c}{ Location } & Belgium & Belgium & France & The \\
Treatments & Flanders & Wallonia & & Netherlands \\
\hline Tax treatment & $65(4)$ & $55(3)$ & $73(4)$ & $64(6)$ & $257(17)$ \\
No-Information & $23(2)$ & $19(1)$ & $33(2)$ & $24(2)$ & $99(7)$ \\
Info-Min & $20(1)$ & $17(1)$ & $20(1)$ & $19(1)$ & $76(4)$ \\
Info-Max & $22(1)$ & $19(1)$ & $20(1)$ & $21(3)$ & $82(6)$ \\
\hline Welfare treatment & $70(4)$ & $59(4)$ & $60(3)$ & $67(7)$ & $256(18)$ \\
No-Information & $28(2)$ & $22(1)$ & $20(1)$ & $23(2)$ & $93(6)$ \\
Info-Min & $23(1)$ & $17(1)$ & $20(1)$ & $20(2)$ & $80(5)$ \\
Info-Max & $19(1)$ & $20(2)$ & $20(1)$ & $24(3)$ & $83(7)$ \\
\hline Total & $135(8)$ & $114(7)$ & $133(7)$ & $131(13)$ & $513(35)$ \\
$\%$ of females & 50.37 & 42.98 & 50.38 & 51.91 & 48.73 \\
\hline Note: The numbers are those of subjects. The numbers of sessions are in parentheses.
\end{tabular}


Table 3. Distribution of choices per treatment, condition, and country

\begin{tabular}{|c|c|c|c|c|c|}
\hline & \multicolumn{2}{|c|}{ Belgium } & \multirow[t]{2}{*}{ France } & \multirow[t]{2}{*}{ Netherlands } & \multirow[t]{2}{*}{ Total } \\
\hline & Flanders & Wallonia & & & \\
\hline \multicolumn{6}{|l|}{ TAX } \\
\hline Percentage of self- & 59.44 (49.11) & $57.09(49.51)$ & $60.50(48.89)$ & $65.05(47.69)$ & 60.64 (48.85) \\
\hline No-Information & $61.01(48.81)$ & 50.53 & 60.10 & $63.75(48.11)$ & $59.36(49.12)$ \\
\hline Info-Min & $52.50(49.98)$ & 48.43 & 62.67 & $64.91(47.77)$ & $57.37(49.46)$ \\
\hline Info-Max & $64.09(48.01)$ & 71.40 & 59.00 & $66.67(47.18)$ & $65.20(47.64)$ \\
\hline Percentage of evaders: & 38.72 (48.72) & $36.48(48.15)$ & $42.60(49.46)$ & $43.96(49.65)$ & $40.65(49.12)$ \\
\hline No-Information & $38.84(48.77)$ & 28.42 & 42.22 & $44.03(49.68)$ & 39.23 (48.83) \\
\hline Info-Min & $35.83(47.99)$ & 34.51 & 42.50 & $48.42(50.02)$ & 40.44 (49.09) \\
\hline Info-Max & $41.21(49.26)$ & 46.32 & 43.33 & $39.84(48.99)$ & $42.56(49.45)$ \\
\hline \multicolumn{6}{|l|}{ WELFARE } \\
\hline Percentage of cumulating & $49.48(50.01)$ & $50.51(50.01)$ & $49.33(50.01)$ & $48.41(49.99)$ & $49.40(50.00)$ \\
\hline No-Information & 49.40 & 53.03 & 48.00 & $46.23(49.89)$ & $49.18(50.00)$ \\
\hline Info-Min & 47.83 & 48.43 & 47.50 & $51.50(50.02)$ & 48.79 (49.99) \\
\hline Info-Max & $51.58(50.01)$ & 49.50 & 52.50 & $47.92(49.99)$ & $50.24(50.01)$ \\
\hline $\begin{array}{l}\text { Percentage of evaders } \\
\text { stricto sensu }\end{array}$ & 46.95 (49.92) & $45.82(49.84)$ & $47.22(49.94)$ & $46.02(49.85)$ & $46.51(49.88)$ \\
\hline No-Information & $45.60(49.84)$ & 47.58 & 44.67 & $42.17(49.42)$ & $45.02(49.76)$ \\
\hline Info-Min & $45.65(49.85)$ & 45.88 & 47.50 & $51.17(50.03)$ & 47.54 (49.95) \\
\hline Info-Max & $50.53(50.04)$ & 43.83 & 49.50 & $45.42(49.82)$ & 47.19 (49.93) \\
\hline
\end{tabular}

Note: The numbers refer to proportions of subjects. These proportions are obtained from the total number of subjects by treatment and/or condition (see details in Table 2). Standard deviations are in parentheses. 
Table 4. Determinants of the decision to conceal income by information condition

\begin{tabular}{|c|c|c|c|c|}
\hline $\begin{array}{l}\text { Dependent variable: no } \\
\text { report }\end{array}$ & All conditions & $\begin{array}{c}\text { No-Information } \\
\text { condition }\end{array}$ & $\begin{array}{l}\text { Info-Min } \\
\text { condition }\end{array}$ & $\begin{array}{l}\text { Info-Max } \\
\text { condition }\end{array}$ \\
\hline Tax treatment & $\begin{array}{c}-.249 * * *(.064) \\
/-.060 /\end{array}$ & $\begin{array}{c}-.278 * * *(.102) \\
/-.067 /\end{array}$ & $\begin{array}{c}-.280 * *(.128) \\
/-.065 /\end{array}$ & $\begin{array}{c}-.218 * *(.101) \\
/-.052 /\end{array}$ \\
\hline $\begin{array}{l}\text { Condition } \\
\quad \text { No Information }\end{array}$ & Ref. & & & \\
\hline Info-Min condition & $\begin{array}{c}.084(.079) \\
/ .020 /\end{array}$ & - & - & - \\
\hline Info-Max condition & $\begin{array}{c}.130 *(.074) \\
/ .032 /\end{array}$ & - & - & - \\
\hline Audit policy & & & & \\
\hline Audit probability: $1 / 6$ & Ref. & Ref. & Ref. & Ref. \\
\hline Audit probability: $1 / 4$ & $\begin{array}{c}-.971 * * *(.042) \\
/-.235 /\end{array}$ & $\begin{array}{c}-1.035 * * *(.067) \\
/-.250 /\end{array}$ & $\begin{array}{c}-1.023 * * *(.082) \\
/-.238 /\end{array}$ & $\begin{array}{c}-.898 * * *(.070) \\
/-.215 /\end{array}$ \\
\hline Audit probability: $1 / 2$ & $\begin{array}{c}-2.677 * * *(.074) \\
/-.649 /\end{array}$ & $\begin{array}{c}-2.721 * * *(.111) \\
/-.657 /\end{array}$ & $\begin{array}{c}-2.759 * * *(.142) \\
/-.643 /\end{array}$ & $\begin{array}{c}-2.683 * * *(.136) \\
/-.643 /\end{array}$ \\
\hline High fixed fine & $\begin{array}{c}-.188 * * *(.028) \\
/-.046 /\end{array}$ & $\begin{array}{c}-.163 * * *(0.046) \\
/-.039 /\end{array}$ & $\begin{array}{c}-.159 * * *(0.054) \\
/-.037 /\end{array}$ & $\begin{array}{c}-.252 * * *(0.049) \\
/-.060 /\end{array}$ \\
\hline Period & $\begin{array}{c}-.001(.001) \\
/-.001 /\end{array}$ & $\begin{array}{c}-.001(.002) \\
/-.001 /\end{array}$ & $\begin{array}{c}-.003(.003) \\
/-.001 /\end{array}$ & $\begin{array}{c}-.001(.002) \\
\quad /<-.001 /\end{array}$ \\
\hline Country & & & & \\
\hline Wallonia & Ref. & Ref. & Ref. & Ref. \\
\hline Flanders & $\begin{array}{c}-.013(.090) \\
/-.003 /\end{array}$ & $\begin{array}{c}.287 * *(.147) \\
/ .069 /\end{array}$ & $\begin{array}{c}-.254(.176) \\
/-.059 /\end{array}$ & $\begin{array}{c}-.253 *(.147) \\
/-.061 /\end{array}$ \\
\hline France & $\begin{array}{c}.247 * * *(.091) \\
/ .060 /\end{array}$ & $\begin{array}{c}.341 * *(.153) \\
/ .082 /\end{array}$ & $\begin{array}{c}.217(.184) \\
/ .050 /\end{array}$ & $\begin{array}{c}.063(.145) \\
/ .015 /\end{array}$ \\
\hline Netherlands & $\begin{array}{c}.097(.090) \\
/ .024 /\end{array}$ & $\begin{array}{c}.308 * *(.147) \\
/ .074 /\end{array}$ & $\begin{array}{c}.191(.161) \\
/ .044 /\end{array}$ & $\begin{array}{c}-.260 *(.143) \\
/-.062 /\end{array}$ \\
\hline Male & $\begin{array}{c}.165 * *(.067) \\
/ .040 /\end{array}$ & $\begin{array}{c}.215 *(.118) \\
/ .052 /\end{array}$ & $\begin{array}{c}.219 *(.134) \\
/ .051 /\end{array}$ & $\begin{array}{c}.122(.106) \\
/ .029 /\end{array}$ \\
\hline Age & $\begin{array}{c}-.008(.009) \\
/<-.001 /\end{array}$ & $\begin{array}{l}.001(.023) \\
/<-.001 /\end{array}$ & $\begin{array}{c}-.087 * * *(.033) \\
/-.020 /\end{array}$ & $\begin{array}{c}-.002(.009) \\
\quad /<-.001 /\end{array}$ \\
\hline Safety index - Holt \& & $-.127 * * *(.024)$ & $-.065^{\#}(.040)$ & $-.201 * * *(.043)$ & $-.151 * * *(.041)$ \\
\hline Laury & /-.031/ & /-.016/ & $/-.047 /$ & /-.036/ \\
\hline Self-reported risk attitude & $\begin{array}{c}.098 * * *(.021) \\
/ .024 /\end{array}$ & $\begin{array}{c}.097 * * *(.032) \\
/ .023 /\end{array}$ & $\begin{array}{c}.103 * *(.042) \\
/ .024 /\end{array}$ & $\begin{array}{c}.084 * * *(.032) \\
/ .020 /\end{array}$ \\
\hline Cognitive performance & $\begin{array}{c}.067 *(.036) \\
/ .016 /\end{array}$ & $\begin{array}{c}-.022(.061) \\
/-.005 /\end{array}$ & $\begin{array}{c}.043(.076) \\
/ .010 /\end{array}$ & $\begin{array}{c}.175 * * *(.054) \\
/ .042 /\end{array}$ \\
\hline $\begin{array}{l}\text { Parents' relative income } \\
\text { category }\end{array}$ & $\begin{array}{c}.007(.015) \\
/ .002 /\end{array}$ & $\begin{array}{c}-.011(.023) \\
/-.003 /\end{array}$ & $\begin{array}{c}-.010(.030) \\
/-.002 /\end{array}$ & $\begin{array}{c}.030(.027) \\
/ .007 /\end{array}$ \\
\hline Opinion on: & & & & \\
\hline Cheat if get away & $\begin{array}{c}-.003(.021) \\
/-.001 /\end{array}$ & $\begin{array}{c}-.010(.035) \\
/-.003 /\end{array}$ & $\begin{array}{c}-.019(.039) \\
/-.004 /\end{array}$ & $\begin{array}{c}.028(.036) \\
/ .007 /\end{array}$ \\
\hline Pay in cash & $\begin{array}{c}-.013(.024) \\
/-.003 /\end{array}$ & $\begin{array}{c}-.021(.038) \\
/-.005 /\end{array}$ & $\begin{array}{c}.044(.048) \\
/ .010 /\end{array}$ & $\begin{array}{c}-.067(.044) \\
/-.016 /\end{array}$ \\
\hline Tax evasion & $\begin{array}{c}.038 * *(.015) \\
/ .009 /\end{array}$ & $\begin{array}{c}.038^{\# \#}(.023) \\
/ .009 /\end{array}$ & $\begin{array}{c}.061 * *(.029) \\
/ .014 /\end{array}$ & $\begin{array}{c}.030(.025) \\
/ .007 /\end{array}$ \\
\hline Social fraud & $\begin{array}{c}-.023(.016) \\
/-.005 /\end{array}$ & $\begin{array}{c}-.044(.027) \\
/-.011 /\end{array}$ & $\begin{array}{c}-.025(.027) \\
/-.006 /\end{array}$ & $\begin{array}{c}-.011(.027) \\
/-.003 /\end{array}$ \\
\hline $\begin{array}{l}\text { Rich pay too much } \\
\text { taxes }\end{array}$ & $\begin{array}{c}.054(.065) \\
/ .013 /\end{array}$ & $\begin{array}{c}.125(.100) \\
/ .030 /\end{array}$ & $\begin{array}{c}.066(.134) \\
/ .015 /\end{array}$ & $\begin{array}{c}-.022(.109) \\
/-.005 /\end{array}$ \\
\hline Constant & $1.069 * * *(.322)$ & $.677(.553)$ & $3.201 * * *(.888)$ & $1.280 * * *(.496)$ \\
\hline $\begin{array}{l}\text { Number of observations } \\
\text { Log pseudolikelihood } \\
\text { Wald } \chi^{2}\end{array}$ & $\begin{array}{c}15390 \\
-6641.298 \\
1420.97 \\
\end{array}$ & $\begin{array}{c}5760 \\
-2475.234 \\
675.91 \\
\end{array}$ & $\begin{array}{c}4680 \\
-1938.784 \\
467.63 \\
\end{array}$ & $\begin{array}{c}4950 \\
-2115.248 \\
498.91 \\
\end{array}$ \\
\hline
\end{tabular}




\begin{tabular}{|l|c|c|c|c|}
\hline Prob $>\chi^{2}$ & .0000 & .0000 & .0000 & .0000 \\
Pseudo $\mathrm{R}^{2}$ & .370 & .368 & .396 & .379 \\
\hline
\end{tabular}

Note: $* * *$, and $* * *$ indicate significance at the $10 \%, 5 \%$ and $1 \%$ level, respectively. Robust standard errors are in parentheses and marginal effects between brackets. ${ }^{\#}$ indicates significance at $10.4 \%$ and ${ }^{\#}$ at $10.3 \%$. Tax treatment, Info-Min condition, Info-Max condition, audit probability $1 / 4$ and $1 / 2$, high fixed fine, Flanders, France, the Netherlands, and male are dummy variables. The safety index is given by the number of times the participant has chosen the safe option A in the Holt and Laury lottery and can take any integer value between 0 and 10 (ex ante measure). The self-reported risk attitude takes a value between 1 (risk averse) and 9 (willing to take full risks) (ex post measure). Cognitive performance indicates the number of correct answers in the three questions of the Cognitive Reflection test. The parents' relative income category is given by the answer to the question "how do your parents' income compare with that of the other students of your University?). It can take a value between 1 (among the $10 \%$ the poorest) and 10 (among the $10 \%$ the richest). The opinion on "Cheat if get away" and on "Pay in cash" can take a value between 1 (this behavior is perfectly acceptable) and 6 (this behavior is not at all acceptable). The opinion on "Tax evasion" and on "Social fraud" is coded in the opposite direction: 1 indicates that the behavior is absolutely unacceptable while 10 indicates that it is absolutely acceptable. The opinion on "Rich pay too much taxes" is coded 1 if the participant answered "agree" or "strongly agree" to the following statement: "Rich pay too much taxes", and 0 otherwise. 
Tableau 5. Determinants of decisions by treatment

\begin{tabular}{|c|c|c|c|c|}
\hline \multirow[b]{2}{*}{ Dependent variables } & \multicolumn{2}{|c|}{ Tax treatment } & \multicolumn{2}{|c|}{ Welfare treatment } \\
\hline & $\begin{array}{l}\text { Choice of a self- } \\
\text { employed job } \\
\text { (1) }\end{array}$ & Evasion & $\begin{array}{c}\text { Cumulating } \\
\text { welfare benefits } \\
\text { and black job } \\
\text { (3) }\end{array}$ & Evasion \\
\hline \multicolumn{5}{|l|}{ Condition } \\
\hline No-Information & Ref. & Ref. & Ref. & Ref. \\
\hline Info-Min & $-.027(0.123)$ & $.114(.114)$ & $-.074(.121)$ & $.158(.171)$ \\
\hline Info-Max & $.246 * *(0.119)$ & $-.009(.114)$ & $.077(.116)$ & $.138(.108)$ \\
\hline \multicolumn{5}{|l|}{ Audit policy } \\
\hline Audit probability: 1/6 & Ref. & Ref. & Ref. & Ref. \\
\hline Audit probability: $1 / 4$ & $-.835 * * *(.073)$ & $-.528 * * *(.107)$ & $-1.359 * * *(.086)$ & $-1.199 * * *(.115)$ \\
\hline Audit probability: $1 / 2$ & $-2.161 * * *(.102)$ & $-1.884 * * *(.377)$ & $-3.146 * * *(.133)$ & $-2.892 * * *(.216)$ \\
\hline High fixed fine & $-.246 * * *(.034)$ & $-.156 * * *(.050)$ & $-.094 * *(.045)$ & $-.113 * *(.045)$ \\
\hline Gross income & - & $.001 * * *(<.001)$ & - & $-.001(<.001)$ \\
\hline Period & $.001(.002)$ & $-.001(.002)$ & $-.002(.002)$ & $-.003(.002)$ \\
\hline \multicolumn{5}{|l|}{ Country } \\
\hline Wallonia & Ref. & Ref. & Ref. & Ref. \\
\hline Flanders & $.031(.158)$ & $-.026(.134)$ & $-.068(.132)$ & $.067(.161)$ \\
\hline France & $.347 * *(.153)$ & $.387 * * *(.148)$ & $-.060(.141)$ & $.146(.170)$ \\
\hline Netherlands & $.307 * *(.142)$ & $.089(.142)$ & $-.136(.127)$ & $.027(.146)$ \\
\hline Male & $.067(.102)$ & $.165^{\#}(.101)$ & $.070(.102)$ & $.195 *(.107)$ \\
\hline Age & $-.013(.012)$ & $-.013(.011)$ & $.004(.017)$ & $.006(.015)$ \\
\hline Safety index - Holt \& Laury & $-.080 * *(.034)$ & $-.075 * *(.035)$ & $-.162 * * *(.045)$ & $-.168 * * *(.042)$ \\
\hline Self-reported risk attitude & $.102 * * *(.033)$ & $.036(.030)$ & $.157 * * *(.036)$ & $.133 * * *(.035)$ \\
\hline Cognitive performance & $.135 * * *(.052)$ & $.061(.052)$ & $.010(.056)$ & $.048(.054)$ \\
\hline Parents' relative income & $-.018(.026)$ & $.045 * *(.023)$ & $-.013(.024)$ & $-.003(.023)$ \\
\hline \multicolumn{5}{|l|}{ Opinion on: } \\
\hline Cheat if get away & $-.046(.034)$ & $-.012(.030)$ & $.051(.033)$ & $.032(.032)$ \\
\hline Pay in cash & $.005(.037)$ & $.019(.031)$ & $-.055(.041)$ & $-.072 *(.040)$ \\
\hline Tax evasion & $.052 *(.027)$ & $.028(.023)$ & $.027(.022)$ & $.021(.022)$ \\
\hline Social fraud & $-.006(.023)$ & $-.027(.023)$ & $-.035(.029)$ & $-.041(.028)$ \\
\hline Rich pay too much & $.259 * *(.108)$ & $.075(.099)$ & $-.032(.107)$ & $-.049(.101)$ \\
\hline Constant & $1.155 * * *(.433)$ & $.543(.403)$ & $1.602 * *(.630)$ & $1.568 * * *(.568)$ \\
\hline Number of observations & 7710 & 4675 & 7680 & 3794 \\
\hline Log-likelihood/pseudo lik. & \multicolumn{2}{|c|}{-6002.902} & \multicolumn{2}{|c|}{-3574.149} \\
\hline Wald $\chi^{2}$ & \multicolumn{2}{|c|}{77.21} & \multicolumn{2}{|c|}{678.46} \\
\hline Prob $>\chi^{2}$ & \multicolumn{2}{|c|}{0.000} & \multicolumn{2}{|c|}{0.000} \\
\hline$\rho$ & \multicolumn{2}{|c|}{.014} & \multicolumn{2}{|c|}{$.988 *$} \\
\hline
\end{tabular}

Note: $*, * *$, and $* * *$ indicate significance at the $10 \%, 5 \%$ and $1 \%$ level, respectively. Robust standard errors are in parentheses. " indicates significance at 10.3\%. Info-Min condition, Info-Max condition, audit probability $1 / 4$ and $1 / 2$, high fixed fine, Flanders, France, the Netherlands, and male are dummy variables. The gross income takes the value of the perceived income divided by 100 . The safety index is given by the number of times the participant has chosen the safe option A in the Holt and Laury lottery and can take any integer value between 0 and 10 (ex ante measure). The self-reported risk attitude takes a value between 1 (risk averse) and 9 (willing to take full risks) (ex post measure). Cognitive performance indicates the number of correct answers in the three questions of the Cognitive Reflection test. The parents' relative income category is given by the answer to the question 'how do your parents' income compare with that of the other students of your University?). It can take a value between 1 (among the 10\% the poorest) and 10 (among the 10\% the richest). The opinion on "Cheat if get away" and on "Pay in cash" can take a value between 1 (this behavior is perfectly acceptable) and 6 (this behavior is not at all acceptable). The opinion on "Tax evasion" and on "Social fraud" is coded in the opposite direction: 1 indicates that the behavior is absolutely unacceptable while 10 indicates that it is absolutely acceptable. The opinion on "Rich pay too much taxes" is coded 1 if the participant answered "agree" or "strongly agree" to the following statement: "Rich pay too much taxes", and 0 otherwise. 
Appendix A. Instructions of the Tax treatment under the Information condition (The instructions for the No-Information are similar except for the sentences that are underlined below-but were not underlined in the instructions distributed to the subjects)

We thank you for taking part in this experiment on decision-making. In the experiment, your earnings will depend on your decisions and random events. It is important that you carefully read these instructions. The experiment consists of three independent parts. At the end of the experiment, you will be paid the sum of your earnings in these parts. In addition, you will receive 3 Euro for showing up on time. You will be paid in cash your earnings at the end of the session individually and confidentially.

All your decisions are anonymous. You will never enter your name in the computer.

During the experiment you are not allowed to communicate. If you have questions then please raise your hand. One of us will come to you to answer your question.

You have received the instructions for the first part. You will receive the instructions for the second and the third part after you have completed the first part.

\section{Part 1}

During this part, you will make ten successive decisions. At the end of the experiment, one of these decisions will be randomly drawn by the computer software for determining your earnings.

Each decision is a paired choice between "Option A" and "Option B". All the decisions and options are displayed in the table below. They will be also displayed on your computer screen. You will have to choose between these options by clicking either option A or option B.

- $\quad$ Look at Decision 1.

Option A pays $2 €$ with 1 chance out of 10 and it pays $1.6 €$ with 9 chances out of 10

Option B pays $3.85 €$ with 1 chance out of 10 and it pays $0.1 €$ with 9 chances out of 10

- $\quad$ Look at Decision 2.

Option A pays $2 €$ with 2 chances out of 10 and it pays $1.6 €$ with 8 chances out of 10

Option B pays $3.85 €$ with 2 chances out of 10 and it pays $0.1 €$ with 8 chances out of 10

The other eight decisions are similar. Note that as you move down the table, the chances of a higher prize for each option increase. In fact, for Decision 10 each option pays the highest payoff for sure, so your choice here is between $2 €$ and $3.85 €$

To summarize:

- You make ten decisions. For each decision, you choose between Option A and Option B. You may choose A for some decisions and B for others. There are no correct or incorrect answers.

- $\quad$ After you have made your ten decisions, you must confirm this set of decisions by clicking the OK button. Once you have clicked this button, you can no longer change your decisions.

- At the end of the session, the computer software will select randomly one of your ten decisions. Each decision has an equal chance of being relevant for your earnings. Thereafter, with a new random draw, the computer program will determine your money earnings for the option (A or B) you chose for that decision according to the chances indicated for the option you chose.

If you have any question, please raise your hand. Your questions will be answered in private.

The ten decisions 


\section{Decision 1}

Option A: 1 chance out of 10 of receiving $2 €$ and 9 chances out of 10 of receiving $1.6 €$

Option B: 1 chance out of 10 of receiving $3.85 €$ and 9 chances out of 10 of receiving $0.1 €$

1. Decision 2

Option A: 2 chances out of 10 of receiving $2 €$ and 8 chances out of 10 of receiving $1.6 €$ Option B: 2 chances out of 10 of receiving $3.85 €$ and 8 chances out of 10 of receiving $0.1 €$

2. Decision 3

Option A: 3 chances out of 10 of receiving $2 €$ and 7 chances out of 10 of receiving $1.6 €$ Option B: 3 chances out of 10 of receiving $3.85 €$ and 7 chances out of 10 of receiving $0.1 €$

3. Decision 4

Option A: 4 chances out of 10 of receiving $2 €$ and 6 chances out of 10 of receiving $1.6 €$

Option B: 4 chances out of 10 of receiving $3.85 €$ and 6 chances out of 10 of receiving $0.1 €$

4. Decision 5

Option A: 5 chances out of 10 of receiving $2 €$ and 5 chances out of 10 of receiving $1.6 €$

Option B: 5 chances out of 10 of receiving $3.85 €$ and 5 chances out of 10 of receiving $0.1 €$

5. Decision 6

Option A: 6 chances out of 10 of receiving $2 €$ and 4 chances out of 10 of receiving $1.6 €$

Option B: 6 chances out of 10 of receiving $3.85 €$ and 4 chances out of 10 of receiving $0.1 €$

6. Decision 7

Option A: 7 chances out of 10 of receiving $2 €$ and 3 chances out of 10 of receiving $1.6 €$

Option B: 7 chances out of 10 of receiving $3.85 €$ and 3 chances out of 10 of receiving $0.1 €$

7. Decision 8

Option A: 8 chances out of 10 of receiving $2 €$ and 2 chances out of 10 of receiving $1.6 €$

Option B: 8 chances out of 10 of receiving $3.85 €$ and 2 chances out of 10 of receiving $0.1 €$

8. Decision 9

Option A: 9 chances out of 10 of receiving $2 €$ and 1 chance out of 10 of receiving $1.6 €$

Option B: 9 chances out of 10 of receiving $3.85 €$ and 1 chance out of 10 of receiving $0.1 €$

9. Decision 10

Option A: 10 chances out of 10 of receiving $2 €$ and 0 chance out of 10 of receiving $1.6 €$

Option B: 10 chances out of 10 of receiving $3.85 €$ and 0 chance out of 10 of receiving $0.1 €$

Part 2 (Instructions distributed after part 1 has been completed)

During this part, your earnings are counted in points. Your earnings in cash from this part will be calculated according to the following conversion rate:

$$
100 \text { points }=€ 3
$$

This part consists of 30 independent periods. At the end of the experiment, the computer program will randomly select two of these periods for payment, where each period has the same chance to be chosen. Your earnings in this part will be the average of your payoffs in these two periods.

\section{Description of each period}

In each period, you must choose between taking a salaried job or a self-employed job. Each job lasts only one period.

- Each job is associated with various possible gross incomes.

* In a salaried job, your gross income can take the value 200, 300, 450, 550, 650 or 750 points.

* In a self-employed job, your gross income can take the value 150, 200, 350, 550, 750 or 850 points.

After you have made your choice between a salaried job and a self-employed job, the computer program selects randomly your gross income for this period and you will be informed about it.

a Any income should be reported such that it can be taxed. The unique tax rate is $25 \%$.

* In a salaried job, your income will be automatically taxed and the net (= after tax) income amounts to $75 \%$ of your gross income. Therefore your net income can take the value $150,225,337.5,412.5,487.5$ or 562.5 points, depending on your gross income.

* In a self-employed job, you will make a second decision. You will choose between reporting your self- 
employment income or not reporting it.

If you do report your income, it will be taxed at $25 \%$. Your net income will amount to $75 \%$ of the gross income from self-employment. Therefore, your net income can take the value 112.5, 150, 262.5, 412.5, 562.5 or 637.5 points, depending on your gross income.

If you do not report your self-employment income, you can be audited according to a certain audit probability. This audit probability can vary across periods. There are 3 different audit probabilities (it can be 1 chance out of 6 , or 1 chance out of 4 , or 1 chance out of 2). The consequences of an audit are described below. There are 2 possible cases.

- If you are not audited, your net income is equal to your gross income. It can take the value 150,200 , $350,550,750$ or 850 points, depending on your gross income.

- If you are audited, your income is taxed at $25 \%$ and a fine has to be paid. The fine amounts to $25 \%$ of your gross self-employment income plus a fixed amount of 50 or 75 , depending on the period. In periods where the fixed amount of the fine amounts to 50 points, your final income can take the value $25,50,125,225,325$ or 375 points, depending on your gross self-employment income.

In periods where the fixed amount of the fine amounts to 75 points, your final income can take the value 0,25 , $100,200,300$ or 350 points, depending on your gross self-employment income.

\section{口 Information}

At the beginning of each period, you are informed on the probability of an audit and on the fixed amount of the fine in that period.

You also receive information on the decisions of participants who in some previous experiments were in the same conditions as you are now. More precisely, before making your decision, you are informed on the proportion of participants who chose the salaried job and the proportion of those who chose the self-employed job in previous experiments for the same audit probability and the same fixed amount of the fine as you.

In addition, if you choose the self-employed job, after learning your gross income you are informed on the proportion of participants in some previous experiments who made the same choice and who received the same. gross income, chose to report and the proportion of participants who chose not to report.

In these previous experiments the rules were the same as in this experiment, except that the participants did not have such information.

At the end of each period, you are informed on whether you have been audited (in case you have chosen the selfemployed job and did not report) and on your final income in this period. Thereafter, a new period will start automatically.

To sum up, in each period:

- at the beginning you are informed on the probability of an audit and on the fixed amount of the fine;

- you are also informed about the decisions of participants in some previous experiments for the same. probability of audit and the same fixed amount of the fine as you;

- you choose between a salaried job and a self-employed job;

- you are informed on your gross income;

- if you have chosen a self-employed job, you are also informed about the decisions of participants in. some previous experiments before you choose between reporting your self-employment income or not reporting it;

- if you have chosen a self-employed job and did not report you are informed on whether you have been audited;

- at the end you are informed about your final income in this period.

The table in appendix summarizes all possible gross and net incomes.

\section{Part 3 and end of the session}

In this part we ask you to answer several questions about you and your opinions. All your answers are anonymous and will be kept confidential. We appreciate if you answer all questions sincerely.

At the end of part 3 , the computer program will calculate and show your total earnings from part 1 and for part 2. Thereafter, you will be paid out anonymously and confidentially.

During the whole experiment you are not allowed to communicate in any way with other participants. If you 
have a question, please raise your hand; your question will be answered in private.

Before we start the experiment we ask you to answer a few questions in order to test your understanding of the instructions. These questions will appear on your computer screen shortly.

Appendix: Table of incomes (in points)

\begin{tabular}{|c|c|c|c|c|c|c|}
\hline \multicolumn{7}{|c|}{ SALARIED JOB } \\
\hline If your gross income is: & 200 & 300 & 450 & 550 & 650 & 750 \\
\hline Your net (after tax) income is: & 150 & 225 & 337.5 & 412.5 & 487.5 & 562.5 \\
\hline \multicolumn{7}{|c|}{ SELF-EMPLOYED JOB } \\
\hline If your gross income is: & 150 & 200 & 350 & 550 & 750 & 850 \\
\hline $\begin{array}{l}\text { Your net income if the gross income from the self- } \\
\text { employed job is reported is: }\end{array}$ & 112.5 & 150 & 262.5 & 412.5 & 562.5 & 637.5 \\
\hline \multicolumn{7}{|l|}{$\begin{array}{l}\text { Your net income if the gross income from the self- } \\
\text { employed job is not reported and }\end{array}$} \\
\hline - not audited & 150 & 200 & 350 & 550 & 750 & 850 \\
\hline - audited with a fixed amount of the fine $=\mathbf{5 0}$ & 25 & 50 & 125 & 225 & 325 & 375 \\
\hline - audited with a fixed amount of the fine $=\mathbf{7 5}$ & $\mathbf{0}$ & 25 & 100 & 200 & 300 & 350 \\
\hline
\end{tabular}

\section{Appendix B. Instructions of the Welfare treatment under the Information condition} (The instructions for the No-Information are similar except for the sentences that are underlined below -but were not underlined in the instructions distributed to the subjects)

The instructions for the introduction and the first part are identical to that of the tax treatment and are therefore omitted in this appendix.

Part 2 (Instructions distributed after part 1 has been completed)

During this part, your earnings are counted in points. Your earnings in cash from this part will be calculated according to the following conversion rate:

$$
100 \text { points }=€ 3
$$

This part consists of 30 independent periods. At the end of the experiment, the computer program will randomly select two of these periods for payment, where each period has the same chance to be chosen. Your earnings in this part will be the average of your payoffs in these two periods. 


\section{Description of each period}

In each period, you must choose between taking a salaried job or cumulating a welfare benefit and a job on the black market. Each job lasts only one period.

- Each job is associated with various possible gross incomes.

* In a salaried job, your gross income can take the value $200,300,450,550,650$ or 750 points.

* By cumulating the welfare benefit and a black market job, your gross income can take the value 150, 200, 350, 550,750 or 850 points. Depending on the period, this includes a welfare benefit of 100 points or 150 points.

After you have made your choice between a salaried job and cumulating a welfare benefit and a black market job, the computer program selects randomly your gross income for this period and you will be informed about it.

- Any income should be reported such that it can be taxed. The unique tax rate is $25 \%$.

* In a salaried job, your income will be automatically taxed and the net (= after tax) income amounts to $75 \%$ of your gross income. Therefore your net income can take the value 150, 225, 337.5, 412.5, 487.5 or 562.5 points, depending on your gross income.

* If you cumulate a welfare benefit and a black market job, you will make a second decision. You will choose between reporting your black market income job or not reporting it.

If you do report your black market income, it will be taxed at $25 \%$ and you will lose your welfare benefit. Your net income will amount to $75 \%$ of your gross income on the black market. Therefore, in periods where the welfare benefit amounts to 100 points, your net income can take the value $37.5,75,187.5,337.5,487.5$ or 562.5 points, depending on your gross income. In periods where the welfare benefit amounts to 150 points, your net income can take the value $0,37.5,150,300,450$, or 525 points, depending on your gross income.

If you do not report your black market income, you can be audited according to a certain audit probability. This audit probability can vary across periods. There are 3 different audit probabilities (it can be 1 chance out of 6 , or 1 chance out of 4 , or 1 chance out of 2 ). The consequences of an audit are described below. There are 2 possible cases.

- If you are not audited, your net income is equal to the welfare benefit and your gross income in the black market job. It can take the value $150,200,350,550,750$ or 850 points, depending on your gross income.

- If you are audited, your black market income is taxed at $25 \%$, a fine has to be paid, and your welfare benefit is lost.The fine amounts to $25 \%$ of your gross black market income. In periods where the welfare benefit amounts to 100 points, your final income can take the value 25,50 , $125,225,325$ or 375 points, depending on your gross black market income.

In periods where the welfare benefit amounts to 150 points, your final income can take the value 0,25 , $100,200,300$ or 350 points, depending on your gross black market income.

\section{- Information}

At the beginning of each period, you are informed on the probability of an audit and on the amount of the welfare benefit in that period.

You also receive information on the decisions of participants who in some previous experiments were in the same conditions as you are now. More precisely, before making your decision, you are informed on the proportion of participants who chose the salaried job and the proportion of those who chose to cumulate the welfare benefit and the black market job in previous experiments for the same audit probability and the same. welfare benefit as you.

In addition, if you choose to cumulate the welfare benefit and the black market job, after learning your gross. black market income you are informed on the proportion of participants in some previous experiments who made the same choice and who received the same gross black market income, chose to report and the proportion of participants who chose not to report.

In these previous experiments the rules were the same as in this experiment, except that the participants did not. have such information. 
At the end of each period, you are informed on whether you have been audited (in case you have chosen to cumulate a welfare benefit and a black market job and did not report) and on your final income in this period. Thereafter, a new period will start automatically.

To sum up, in each period:

at the beginning you are informed on the probability of an audit and on the amount of the welfare benefit;

a you are also informed about the decisions of participants in some previous experiments for the same. probability of audit and the same welfare benefit as you;

a you choose between a salaried job and cumulating a welfare benefit and a black market job;

a you are informed on your gross income;

- if you have chosen to cumulate a welfare benefit and a black market job, you are also informed about the decisions of participants in some previous experiments before you choose between reporting your black market income or not reporting it;

- if you have chosen to cumulate a welfare benefit and a black market job and did not report it, you are informed on whether you have been audited;

a at the end you are informed about your final income in this period.

The table in appendix summarizes all possible gross and net incomes.

\section{Part 3 and end of the session}

In this part we ask you to answer several questions about you and your opinions. All your answers are anonymous and will be kept confidential. We appreciate if you answer all questions sincerely.

At the end of part 3, the computer program will calculate and show your total earnings for part 1 and for part 2. Thereafter, you will be paid out anonymously and confidentially.

During the whole experiment you are not allowed to communicate in any way with other participants. If you have a question, please raise your hand; your question will be answered in private.

Before we start the experiment we ask you to answer a few questions in order to test your understanding of the instructions. These questions will appear on your computer screen shortly. 
Appendix: Table of incomes (in points)

\section{SALARIED JOB}

\begin{tabular}{|l|c|c|c|c|c|c|}
\hline If your gross income is: & 200 & 300 & 450 & 550 & 650 & 750 \\
\hline Your net (after tax) income is: & $\mathbf{1 5 0}$ & $\mathbf{2 2 5}$ & $\mathbf{3 3 7 . 5}$ & $\mathbf{4 1 2 . 5}$ & $\mathbf{4 8 7 . 5}$ & $\mathbf{5 6 2 . 5}$ \\
\hline
\end{tabular}

\begin{tabular}{|c|c|c|c|c|c|c|}
\hline \multicolumn{7}{|c|}{ WELFARE BENEFIT AND BLACK MARKET JOB IF THE WELFARE BENEFIT $=100$} \\
\hline If your gross income is: & 150 & 200 & 350 & 550 & 750 & 850 \\
\hline$=$ black market job income + & 50 & 100 & 250 & 450 & 650 & 750 \\
\hline welfare benefit & 100 & 100 & 100 & 100 & 100 & 100 \\
\hline \multicolumn{7}{|l|}{ Your net income is: } \\
\hline if the gross black market income is reported & 37.5 & 75 & 187.5 & 337.5 & 487.5 & 562.5 \\
\hline \multicolumn{7}{|c|}{ if the gross black market income is not reported and: } \\
\hline - not audited & 150 & 200 & 350 & 550 & $\mathbf{7 5 0}$ & 850 \\
\hline - audited & 25 & 50 & 125 & 225 & 325 & 375 \\
\hline
\end{tabular}

WELFARE BENEFIT AND BLACK MARKET JOB IF THE WELFARE BENEFIT $=150$

\begin{tabular}{|c|c|c|c|c|c|c|}
\hline If your gross income is: & 150 & 200 & 350 & 550 & 750 & 850 \\
\hline$=$ black market income & 0 & 50 & 200 & 400 & 600 & 700 \\
\hline+ welfare benefit & 150 & 150 & 150 & 150 & 150 & 150 \\
\hline \multicolumn{7}{|l|}{ Your net income is: } \\
\hline if the gross black market income is reported & $\mathbf{0}$ & 37.5 & 150 & 300 & 450 & 525 \\
\hline \multicolumn{7}{|c|}{ if the gross black market income is not reported and: } \\
\hline \multirow{2}{*}{$\begin{array}{l}\text { - not audited } \\
\text { - audited }\end{array}$} & 150 & 200 & 350 & 550 & 750 & 850 \\
\hline & $\mathbf{0}$ & 25 & 100 & 200 & 300 & 350 \\
\hline
\end{tabular}

\section{Appendix C. Post experimental questionnaire}

Your sex: o Female o Male 
Your age: years

Your nationality:

Your study discipline:

o business

o economics

o engineering, computer sciences

o maths, physics, chemistry

o medicine

o others

Your school or university:

Your father's highest finished education:

o no certificate

o vocational training certificate

o high school final exam (baccalaureat)

o university degree

Your mother's highest finished education

o no certificate

o vocational training certificate

o high school final exam (baccalaureat)

o university degree

How many paid hours per week do you work on average next to your study:

Did you take a loan to pay your education?

Do you own a personal car? o yes o no

In your opinion, how do your parents' income compare with that of the other students of your university/school? Your parents are

$\begin{array}{llllclll}1 & 2 & 3 & 4 & \begin{array}{c}5 \\ \text { in the } \\ \text { average }\end{array} & \begin{array}{l}\text { among the } 10 \% \\ \text { the poorest }\end{array} & & \end{array}$

Click 1 if you believe your parents's income is among the lowest 10\%, 2 for the lower 20\%, etc. . Click 5 if you believe your parents' income are average. Click 10 if you believe your parents' incomes are among the highest $10 \%$.

How do you see yourself: Are you generally a person who is fully prepared to take risks or do you try to avoid taking risks?

(1=Risk averse ......9=Willing to take full risk)

Would you define your political opinions as (multiple options possible with a maximum of 2)

right

middle

left

liberal

conservative

green/ecological

religiously inspired

none of the above

Don't know

Please rate the following statements: 
Most crime...

... is committed by unworthy beings, and the government must protect law-abiding citizens and their property. ... is committed by fallen human beings, and the government is honor-bound to help them recover and become good citizens again.

... is a fact of life, and it is the responsibility of each individual to protect him- or herself. The government should not intervene.

none of the above

Don't know

Progressive taxation (i.e. higher tax rates for people with a higher income than for people with lower income)... ... is a just form of taxation, because it takes from those who have and give to those who don't have.

... is bad like all taxation.

... is bad because it is detrimental to efficiency.

none of the above

Don't know

The rich have to pay too much taxes.

Strongly Disagree

Disagree

Agree

Strongly Agree

Don't know

The freer the economy, the freer the people.

Strongly Disagree

Disagree

Agree

Strongly Agree

Don't know

Life on earth was created by some supreme being.

Strongly Disagree

Disagree

Agree

Strongly Agree

Don't know

There is evidence that part of the population is engaged in undeclared work, in the sense of activities which circumvent declaration to tax authorities or social security institutions, but which are otherwise legal. Payment may be in money or in kind. This could be people working in certain sectors of activity like construction, transport or agriculture for example but also in hotels, restaurants and cafes. Undeclared work is also common in the whole range of household services - such as gardening, babysitting and elderly care -, personal services - like hairdressing, cosmetic or medical treatment - and repair services for cars, clothes, or computers.

What would you estimate is the share of the population which works without declaring the income or part of the income to tax or social security institutions in each of the following countries/regions?

\begin{tabular}{|c|c|c|c|c|c|}
\hline $\begin{array}{l}\text { Belgium } \\
\text { Wallonia }\end{array}$ & $\begin{array}{l}\text { Belgium } \\
\text { Flanders }\end{array}$ & France & $\begin{array}{l}\text { Former East } \\
\text { Germany }\end{array}$ & $\begin{array}{l}\text { Former West } \\
\text { Germany }\end{array}$ & Netherlands \\
\hline
\end{tabular}

Less than $1 \%$

From $1 \%$ to less than $5 \%$

From $5 \%$ to less than $10 \%$

From $10 \%$ to less than $20 \%$

From $20 \%$ to less than $30 \%$

From $30 \%$ to less than $40 \%$

From $40 \%$ to less than $50 \%$

$50 \%$ or more

Don't know 
According to you, in your country what is the percentage of chance (between 0 and 100\%) that the Tax authority controls a tax return?

Do you personally know any people who work without declaring their income or part of their income to tax or social security institutions?

o Yes o No o Don't know

In your opinion, which of the following categories are most likely to carry out undeclared work? Please indicate the first and second most likely.

Unemployed

First Second

Self-employed

Pensioners $\backslash$ retired

Full-time employees

Part-time employees

Students

Legal immigrants

Illegal immigrants

Others

Don't know

Have you in the last twelve months acquired any services or goods of which you had a good reason to assume that they embodied undeclared work, i.e. that the income was not completely reported to tax or social security institutions?

Yes

No

Don't know

Do you know anybody who has in the last twelve months acquired any services or goods of which s/he had a good reason to assume that they embodied undeclared work, i.e. that the income was not completely reported to tax or social security institutions?

o Yes o No o Don't know

How do you assess the following behaviours. For each of them, please indicate to what extent you find it acceptable or not. Please use the following scale: '1' means that you find it "absolutely unacceptable" and '10' means that you find it "absolutely acceptable".

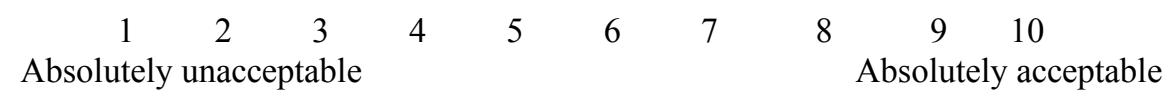

Someone receives welfare payments without being legally entitled

Someone uses public transport without a valid ticket

A private person is hired by a private household for work and he $\backslash$ she does not report the payment received in return to tax or social security institutions although the law requires that it should be reported

A firm is hired by a private household for work and it does not report the payment received in return to tax or social security institutions although the law requires that it should be reported

A firm is hired by another firm for work and it does not report its activity to tax or social security institutions although the law requires that it should be reported

A firm hires a private person and all or a part of the salary paid to him $\backslash$ her is not officially registered although the law requires that it should be reported

Someone evades taxes by not or only partially declaring income 
Please answer the following questions on a scale from 1 to 6 , where 6 means that in your opinion the described behavior is not at all acceptable and 1 means that it is perfectly acceptable.

1. Trading or exchanging goods or services with a friend or neighbor and not reporting it on your tax form.

2. Reporting your main income fully, but not including some small outside income.

3. Being paid in cash for a job and then not reporting it on your tax form.

4. Not reporting some earnings from investments or interest that the government would not be able to find out about.

5. Almost every taxpayer would cheat to some extent if $\mathrm{s} /$ he thought $\mathrm{s} /$ he could get away with it.

6. The chances of getting caught are so low that it is worthwhile trying to cut corners a little on your taxes. 